\title{
Job-to-Job Flows and Wage Dynamics in France and Italy
}

\section{Clémence Berson, ${ }^{1}$ Marta de Philippis, Eliana Viviano ${ }^{2}$}

\author{
January 2020, WP \#756
}

\begin{abstract}
Some recent literature about the U.S. shows that wage dynamics are more influenced by jobto-job flows than by flows into or out of employment. In this paper, we evaluate whether this result holds also for France and Italy, characterized by a different structure of the labor market. Using comparable administrative data we find that, as in the U.S., in both France and Italy realized job-to-job contribute positively to wage growth. However, since these flows are smaller and display much lower cyclicality than in the U.S., their contribution to aggregate wage dynamics is low, while the contribution of flows into and out of employment remains sizeable. We then look closely at the heterogeneity in the probability of changing job and in the associated wage premium by types of workers and firms. We find that job-to-job flows and the associated gain tend to be larger in high-skilled occupations and for permanent workers. Moreover, as in the U.S., individuals are more likely to move to younger firms, which intensively poach workers from other firms. ${ }^{3}$
\end{abstract}

Keywords: Wage Dynamics, Job-to-Job Flows, Transition Probabilities, Phillips Curve JEL classification: E24, E32, J63

\footnotetext{
${ }^{1}$ Banque de France and LIEPP, Sciences Po

${ }^{2}$ Banca d'Italia

${ }^{3}$ The views expressed in this paper are solely those of the authors and do not necessarily reflect those of the Banque de France or Banca d'Italia. We thank Clément Malgouyres for his help with the French data in the initial stage of the project and Raffaella Nizzi for her help with Italian data, Kerstin Holzeu, Herry Hyatt, Fabien Postel-Vinay and Aysegul Sahin for very helpful suggestions and comments. We are also grateful to the participant to the CASD-IAB conference "Advance in Social Sciences Using Administrative and Survey Data" (March 2019), the LAGV and IAAE conferences, seminars of the Universities of Evry and Siena. This work is supported by a public grant overseen by the French National Research Agency (ANR) as part of the "Investissements d'Avenir" program (reference: ANR-10-EQPX-17 Centre d'accès sécurisé aux données - CASD).
} 


\section{NON-TECHNICAL SUMMARY}

Some recent literature about the U.S. outlines the importance of job-to-job flows not only to fully understand the functioning of the reallocation process of workers in more productive firms, but also to explain aggregate wage dynamics and its recent subdued evolution (e.g. Moscarini and Postel-Vinay 2016, henceforth MPV, and Hahn et al. 2018).

In this paper, we empirically test whether and to what extent job-to-job flows influence nominal wage growth in France and Italy. We decompose aggregate wage dynamics by flow types to identify the contribution of hires/separations and job-to-job flows. We show that in both Italy and France stayers, because of their very large weight in total employment, mostly determine aggregate nominal wage dynamics. The contribution of flows into and out of employment is similar to that of flows from one job to another and these movements tend to offset each other, as for the U.S (Hahn et al. 2018).

Theoretically, job-to-job flows can influence wage growth through two channels that MPV (2016a) define as: (i) the "composition" and (ii) the "strategic" effects. The first is the most obvious one: workers quit their job only if they receive a better wage offer. The second arises when employers respond to other firms' poaching by increasing the wages of their workers in order to retain them. The first effect involves those who change job. The second can affect both those who change and those who do not change job, as in MPV (2016a, 2017a).
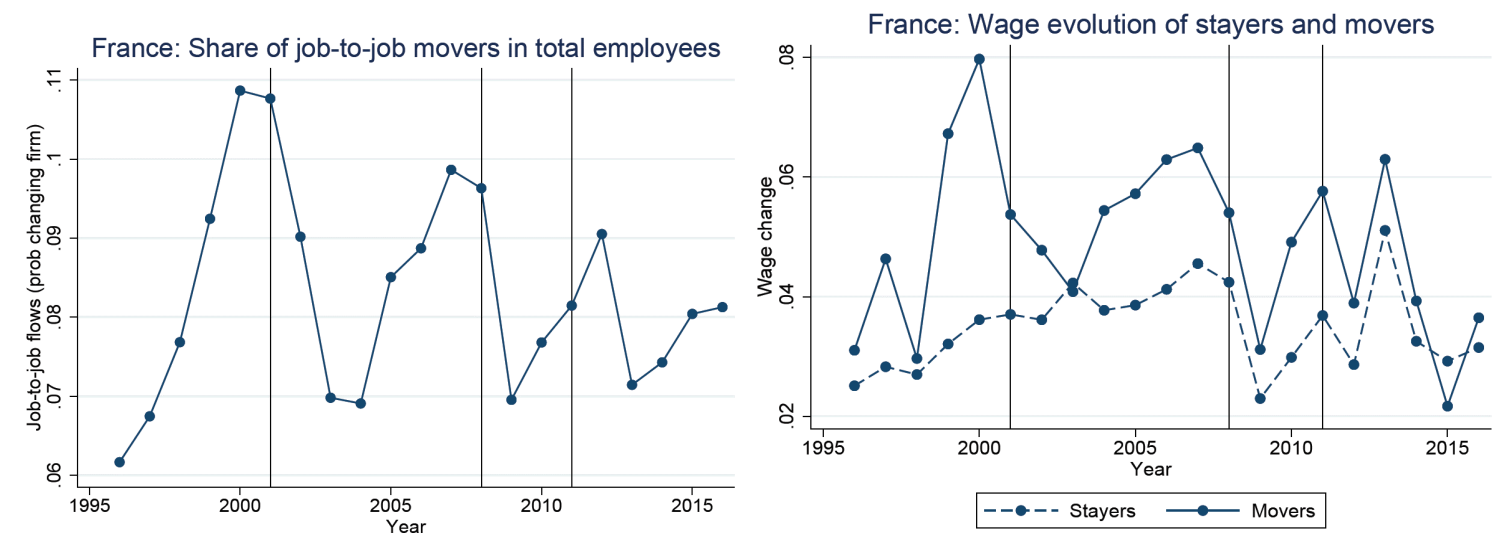

We analyze the correlation of observed job-to-job flows and local shocks, measured by variations in the local unemployment rate. We consider the probability to move to another job, the average wage gain associated to a move and the specific relation of movers' wages with local shocks as opposed to the one of stayers. In our simplest empirical model, the correlation of wage changes with the economic situation is captured by variations in the local unemployment rate where the individual works. We find that in Italy the probability of moving is highly correlated with the local unemployment rate but not in France. In both countries, movers gain on average an extra $2 \mathrm{pp}$. increase in nominal wage growth when they change job. Moreover, this wage gain for movers is significantly negatively correlated with the local unemployment rate. Wage changes of stayers are in general not very responsive to changes in the local economic situation. Comparing France and Italy, we find that job-to-job flows are larger and more correlated with local unemployment in Italy than in France; wage premia instead respond similarly to changes in the local unemployment rate in both countries.

To understand what drives our results, we look at relevant dimensions of heterogeneity. We find supportive evidence that job-to-job flows of workers in high-skilled occupations are more frequent and more sensitive to local economic situation. We also find that temporary workers represent a large share of those who change job, notably because they are forced to look for another job after their contracts expire. The premium from moving, however, is higher and more correlated with the local unemployment rate for permanent workers. We 
also test whether wage dynamics is influenced by firm characteristics. However, we do not find a clear pattern of job-to-job flows by firm size contrary to the literature. If anything, we find that job-to-job flows are more cyclical for small firms. As in Fort et al. (2013), we find that young, small firms poach from other firms, and that both inflows and wage gains are highly and positively correlated with local shocks.

We then look at the existence of the strategic effect, i.e. the reaction of stayers' wages to changes in the average probability of experiencing a job-to-job move in their labour market, as well as of experiencing a change in the average probability of exiting and entering employment in their labour market. We follow MPV (2017a) and, for different types of workers, we calculate a time-varying average probability to register a job-to-job move, a transition from employment to non-employment or a transition from non-employment into employment. We find that flows from job-to-job affect wage growth of both stayers and movers, coherently with the so-called "strategic" effect, as in MPV (2017a). Differently from them, however, we also find that wages respond to variation in potential flows from and to non-employment (which determine changes in the unemployment rate).

Based on our full set of results we conclude that -differently from what observed in the UStransitions into and out of non-employment remain a key determinant of aggregate wage growth. This result supports the validity of the standard Phillips curve specifications. Research about the Phillips curve, however, should also consider the potential impact of jobto-job flows and firm characteristics on aggregate wage growth.

\title{
Une théorie du ralentissement et de l'augmentation des rentes
}

\begin{abstract}
RÉSUMÉ
Certains travaux récents sur les États-Unis montrent que la dynamique des salaires est davantage influencée par les flux d'emploi à emploi que par les flux d'entrée ou de sortie de l'emploi. Dans cet article, nous évaluons si ce résultat vaut également pour la France et l'Italie, caractérisées par une structure différente du marché du travail. En utilisant des données administratives comparables, nous constatons que, comme aux États-Unis, les flux d'emploi à emploi contribuent positivement à la croissance des salaires en France et en Italie. Toutefois, comme ces flux sont plus faibles et présentent un caractère cyclique beaucoup moins important qu'aux États-Unis, leur contribution à la dynamique globale des salaires est faible, tandis que la contribution des flux d'entrée et de sortie de l'emploi reste importante. Nous examinons ensuite de près l'hétérogénéité de la probabilité de changer d'emploi et de la prime salariale associée selon les types de salariés et d'entreprises. Nous constatons que les flux d'emploi à emploi et le gain associé ont tendance à être plus importants dans les professions hautement qualifiées et pour les salariés permanents. En outre, comme aux États-Unis, les individus sont plus susceptibles de se tourner vers des entreprises plus jeunes, qui débauchent intensivement les travailleurs d'autres entreprises
\end{abstract}

Mots-clés : Dynamique des Salaires, Flux d'Emplois, Probabilités de Transition, Courbe de Phillips

Les Documents de travail reflètent les idées personnelles de leurs auteurs et n'expriment pas nécessairement la position de la Banque de France. Ils sont disponibles sur publications.banque-france.fr 


\section{Introduction}

Some recent literature about the U.S. outlines the importance of job-to-job flows not only to fully understand the functioning of the reallocation process of workers in more productive firms, but also to explain aggregate wage dynamics and its recent subdued evolution (e.g. Moscarini and Postel-Vinay, 2016c (henceforth MPV) and Hahn et al., 2018). In particular, the findings of MPV (2016a), MPV (2016b) and Karahan et al. (2017) show that, in empirical models aimed at explaining wage dynamics, hires from employment win the "horse race" against flows from unemployment. They also argue that recent subdued wage growth in the U.S. is better explained by the lack of job-to-job flows than by traditional measures of slack like the unemployment rate. They conclude that policy-makers should pay more attention on the mechanisms behind workers' transitions from one firm to another. These results, however, can be hardly reconciled with the vast literature on the relationship between unemployment and wage dynamics (the Phillips curve framework) and with the literature based on Pissarides (2009), according to which wage cyclicality is determined by new hires from unemployment (see, among others, Shin and Solon, 2007 and Carneiro et al., 2012).

In this paper we use comparable administrative data for France and Italy to empirically test whether and to what extent in these two euro area countries job-to-job flows influence nominal wage growth. Then, we look at heterogeneity of flows by types of workers and firms (large vs small, young vs. old). Finally, we analyse whether variations of flows from and to non-employment contribute to explaining wage growth after controlling for changes in job-to-job flows. We use two distinct panels of matched employer-employee datasets spanning from 1995 to 2016 for France and from 2000 to 2015 for Italy.

Theoretically, job-to-job flows can influence wage growth through two channels that MPV (2016a) define as: (i) the "composition" and (ii) the "strategic" effects. The first is the most obvious one: workers quit their jobs only if they receive a better wage offer. There is therefore a direct positive link between the number of (voluntary) movers in the economy and aggregate wage dynamics. The second is an indirect channel, which arises when employers respond to other firms' poaching by increasing the wages of their workers in order to retain them. The first effect involves those who change job. The second can affect both those who change and those who do not change job/employer, as in MPV (2016a) and MPV (2017a). The evolution of average job-to-job flows is therefore a good proxy for labor demand.

In particular, we look at four types of worker flows: (i) workers who stay in the same firm for two consecutive years, labelled as stayers; (ii) workers who move from one employer to another (movers), (iii) movements from non-employment into employment (entrants), and (iv) vice-versa (exiters). We then decompose aggregate wage dynamics by flow types to identify the contribution of hires/separations and job-to-job flows. We show that in 
both Italy and France aggregate nominal wage dynamics is mostly determined by stayers, because of their very large weight in total employment. Aggregate flows into and out of employment are similar to flows from one job to another and these movements tend to offset each other, as for the U.S (Hahn et al., 2018).

We further look at the composition effect and we analyze the correlation of observed job-to-job flows and local shocks, measured by variations in the local unemployment rate. We consider three elements. The first is the probability to move to another job. The second is the average wage gain associated to a move, if any. The third is the specific relation of movers' wages with local shocks as opposed to the one of stayers. In our simplest empirical model the correlation of wage changes with the economic situation is captured by variations in the local unemployment rate where the individual works (departmental level for France; provincial level for Italy).

We find that in both France and Italy movers gain on average an extra 2 pp. increase in nominal wage growth when they change job, over an average wage growth equal to around $4 \mathrm{pp}$. The probability of moving instead is rather small in these countries and it is very weakly correlated with the local unemployment rate, differently from the findings of Haltiwanger et al., 2018. We also find that in both countries the wage gain of movers is negatively correlated with the local unemployment rate. Last, wage changes of stayers are in general not very responsive to changes in the local economic situation.

To check other implications of the theory, we look at relevant dimensions of heterogeneity. Job-to-job flows should be more frequent and more sensitive to local economic situation for workers in high-skilled occupations. Indeed, MPV (2018) show that, in the presence of heterogeneous human capital and human capital depreciation during unemployment, firms prefer to hire employed workers instead of the unemployed ones. We explicitly test this hypothesis by looking at the probability of moving and at the wage premium associated to changes in employer by type of occupation and we find supportive evidence. We find that temporary workers represent a large share of those who change job, probably because they are forced to look for another job after their contracts expire. The premium from moving is instead higher and more correlated with the local unemployment rate for permanent workers.

We also test whether wage dynamics is influenced by firm characteristics. One natural dimension to look at is firm size, as size is often associated to higher productivity and therefore higher average wage. MPV (2012), for instance, document that in the US large firms have a disproportionate employment response to positive business cycle fluctuation relative to smaller ones, which instead poach workers during downturns. Differently from them, however, we still find a very small cyclical response in the probability of moving, especially towards larger firms. If anything, we find that job-to-job flows are slightly cyclical towards small firms (mostly in Italy). We then follow Fort et al. (2013) and look 
contemporaneously at firm size and age, under the assumption that small and young firms, as opposed to the old-large ones, react more to unemployment fluctuations. As in Fort et al. (2013), we find that young and small firms poach from other firms in Italy and that both inflows and wage gains are positively correlated with local shocks, even if the magnitude of the cyclical response of the probability of moving remains small. This evidence is also in line with Gertler and Gilchrist (1994) and Sharpe (1994) who show that small firms are more subject to higher cyclicality as they are more frequently credit constrained. Compared to France the higher presence of newly-born, small firms in Italy is likely the cause of Italy's slightly larger cyclical responses in the probability of moving.

The evidence discussed so far is in line with the theoretical predictions and empirical results of the literature, except for the magnitude of the effects. We then look at external labor market flows, i.e. those towards and from non-employment, to check for the existence of the so-called strategic effect. This is the potential reaction of stayers' wages to changes in the average probability of experiencing a job-to-job move, or of experiencing a change in the average probability of exiting/entering employment.

We follow MPV (2017a) and, for different types of workers — defined by gender, age, occupation and local labor market-, we calculate a time-varying probability to register (i) a job-to-job move, (ii) a transition from employment towards non-employment (exit) and (iii) a transition from non-employment into employment (entry) in each given year. These probabilities are then used as explanatory variables for wage growth of both stayers and movers. We find that flows from one job to another affect wage growth of both stayers and movers, coherently with the so-called "strategic" effect, as in MPV (2017a). Differently from them, however, we also find that wages respond to variation in potential flows from and to non-employment (which determine changes in the unemployment rate).

Based on our full set of results we conclude that - differently from what observed in the US - unemployment still influences wage growth in France and Italy, as transitions into and out of non-employment remain a key determinant of aggregate wage growth. This result is likely to depend on the limited magnitude and on the low cyclicality of job-to-job movements in the two European countries we consider, which are characterized by more rigid and less mobile labor markets. Our findings support the validity of the unemployment rate as a determinant for wage growth. Research about the Phillips curve, however, should also consider the potential impact of job-to-job flows and firm characteristics on aggregate wage growth.

The paper is organized as follows. Section 2 describes the datasets and our definition of labor market flows and workers' and firms' characteristics. Section 3 presents a decomposition of average wage growth to measure the contribution of job-to-job flows and other flows. In Section 4, we rely on microdata to analyze the probability to move to another job and the impact of external labor market conditions, as summarized by the local unem- 
ployment rate. Section 5 focuses on heterogeneity by type of occupation, job contract and firm structure. Section 6 looks at the direct and strategic effects of job-to-job transitions. Last, Section 7 briefly concludes.

\section{The data}

We use administrative data, drawn from the compulsory declarations that French and Italian companies have to provide to the French National Institute of Statistics (INSEE) and the Italian National Social Security Institute (INPS), respectively. In this section we describe first each dataset and then how we construct labor market flows.

\subsection{French data}

We use a sample of DADS data (Déclarations annuelles de données sociales) for the period 1995-2016. DADS data collect wages of all French employees and are used to compute social security contributions. They constitute the informative basis used by INSEE to produce some of the statistics of wages and employment in France. A panel version of this dataset is available for research purposes. It covers all individuals born in October of each even-numbered years ( $1 / 25^{\text {th }}$ of the working population) for the period 1995-2001 and $1 / 12^{\text {th }}$ of the working population for the period 2002-2016. To avoid over-weighting the most recent part of the sample period, we keep only those born in October of each even-numbered years for years from 2002 to 2016 and, for comparability with the Italian data, we only keep the private-non agricultural sector.

For each year we observe the length of the employment spell in days, its beginning and end dates, the associated wages (including the variable part of compensation and bonuses), the type of contract (since 2005), occupation (blue-collar/low-skilled whitecollar/intermediate profession/professional and manager) and working time (part-time/fulltime). The declared working period includes non-working days. For each worker we observe age, gender and geographical location. For each firm, we match our dataset with the fiscal dataset FARE to obtain information on the average firm size, its age, its geographical location, and the average wage paid to workers 1

\footnotetext{
${ }_{1}^{1}$ Margolis (2002) and Picart (2007) outline the presence of spurious changes in firm identifiers, which imply an overestimation of flows of workers between firms. We adopt their procedure to correct firm identifiers, according to which a change in firm identifier is considered as spurious if two firms have at least one half of workers in common between two consecutive years.
} 


\subsection{Italian data}

Data on employment and wages consist of declarations made by firms to INPS to determine the amount of social security contributions to be paid by all private-sector firms with at least one employee. From this master data, INPS extracts employment histories of all workers born on the $1^{\text {st }}$ or the $9^{\text {th }}$ day of each month $(6.5 \%$ of total workforce in the Italian private sector). This extraction, updated to 2015, provides for each job spell information on workers' demographics, the annual gross wage (before social security contributions), the number of days worked in the year, the main characteristics of the contract (permanent/temporary) and occupation (blue-collar/white-collar/manager), the beginning and end dates of each job spell. As for French data, for each firm, we know its geographical location at the province level, its size, age and the average wage paid to workers.

\subsection{Sample selection and definitions}

Both datasets report the value of wages and days worked by contract and year and we do not observe intra-annual wage variation unless individuals change their job. Thus, we look at the employment status of individuals in December of each year.2

Given the panel structure implicit in our dataset we can identify four types of worker annual flows. The first is composed of individuals who are employed in December of both year $t-1$ and $t$. If they work for the same firm for two consecutive years they are labelled as stayers; if they have changed firm between $t-1$ and $t$ they are labelled as movers. Second we call exiters workers who are working in December $t-1$ but not in $t$; a worker is instead an entrant if she is not working in December $t-1$ but works in $t$.

Some measurement issues can affect our data. First, we do not observe a direct measure of non-employment. Individuals who are not recorded as a private-sector employee in a given year could be either non-employed, or employed in the public sector or working as selfemployed. It is not possible for us to evaluate the size of this potential source of bias, but in both countries the flows of private sector employees from and to public or self-employment are rather small, especially in recent years $3^{3}$ Moreover, to avoid mismeasurement due to retirement or working student, we keep only workers between 25 and 50 years old. We keep all types of workers but our results are robust if we keep only males, full-time and permanent workers (results are reported in the Appendix).

Second, since we are looking at annual transitions, given our definitions, it is possible that we classify as movers also people who, within the same year, lose their job and find a new one after a non-employment spell. To avoid these spurious job-to-job transitions,

\footnotetext{
${ }^{2}$ When the worker has several employment relationships during the same time interval, we keep the one with the longest overall duration and the higher daily wage.

${ }^{3}$ Between 2009 and 2015, 7.7\% of moves are between the public and the private sectors in France using the DADS panel.
} 
we exclude people with an infra-annual non-employment spell longer than one quarter and classify them as entrants. Indeed, one quarter is the time interval used e.g. by Haltiwanger et al., 2018 to define job-to-job flows. In some robustness checks we also exclude people non-employment spells shorter than one month finding similar results.

Finally, in order to have comparable data on wages for the two countries we look at daily wages net of employers' social contributions and before income taxes. The two measures of wages are quite comparable but non-identical, because wages refer to the part of workers' compensation for which firms have to pay social security contributions, with some different rules in the two countries. These differences, however, do not impede us to shed some light on the mechanisms that influence wage dynamics in the two countries, and to compare the size of flows.

Table 1 reports some descriptive statistics and shows some different patterns in France and Italy. In Italy movers account for $10 \%$ of total employees, whereas in France they are around $8 \%$. These shares are remarkably higher if we relate movers to total hires $(43 \%$ in Italy and 29\% in France). The table reports also daily wages of stayers and movers. First, daily wages are apparently slightly higher in Italy than in France, but the difference depends only on the fact that French data refer to the whole period a worker is employed in a firm (including non-working days), whereas Italian data report the actual days worked. With this difference in mind, in both countries those who move have lower daily wages than those who work for the same firm for two consecutive years, but higher wage growth rate. The last rows report the average characteristics of the firms where movers work before moving. In both countries movers typically come from younger and smaller firms. Since we are using samples of workers born in a given date, our samples are representative of the entire population of workers, but not of the population of firms. Table 1 shows this point. In Italy in our sample there are around $47 \%$ firms with at least 50 employees. In France their incidence is even larger (63\%). If we look at the population of firms we find that in Italy only $1.6 \%$ firms are larger than 50 employees. This share is 6 times larger in France.

\section{A look to aggregate data}

To assess the relevance of job-to-job flows and other flows in the labor market, we consider the following decomposition of the average wage change between time $t-1$ and time $t$, $\Delta \overline{w_{t}}$. We define the group of stayers as $S_{t}$, movers as $Q_{t}$, entrants as $N_{t}$ and exiters as $R_{t}$. The employment population is $D_{t}=S_{t}+Q_{t}+N_{t}$ at time $t$ and $D_{t-1}=S_{t}+Q_{t}+R_{t}$ at time $t-1$. 


$$
\Delta \overline{w_{t}}=\underbrace{\frac{\sum_{i} s_{i t} w_{i t}+\sum_{i} q_{i t} w_{i t}+\sum_{i} n_{i t} w_{i t}}{D_{t}}}_{\text {earnings at time t }}-\underbrace{\frac{\sum_{i} s_{i t} w_{i t-1}+\Sigma_{i} q_{i t} w_{i t-1}+\sum_{i} r_{i t} w_{i t-1}}{D_{t-1}}}_{\text {earnings at time t-1 }}
$$

We can separate each part of the equation by transition type:

$$
\begin{array}{r}
\Delta \overline{w_{t}}=\underbrace{\frac{\frac{S_{t}}{D_{t}}+\frac{S_{t}}{D_{t-1}}}{2} \frac{\Sigma_{i} s_{i t} \Delta w_{i t}}{S_{t}}+\underbrace{\frac{Q_{t}}{D_{t}}+\frac{Q_{t}}{D_{t-1}}}_{\text {emp-to-emp. }} \frac{\Sigma_{i} q_{i t} \Delta w_{i t}}{Q_{t}}}_{\text {job stayers }}+ \\
\underbrace{\frac{N_{t}}{D_{t}}\left(\frac{\Sigma_{i} n_{i t} w_{i t}}{N_{t}}-\tilde{w}_{t}\right)-\frac{R_{t}}{D_{t}}\left(\frac{\Sigma_{i} r_{i t} w_{i t-1}}{R_{t}}-\tilde{w}_{t}\right)}_{\text {new hires and exiters }}
\end{array}
$$

where, $s_{i t}, q_{i t}, n_{i t}$ and $r_{i t}$ are indicator variables that refer to stayers, movers, entrants and exiters, respectively, and $\tilde{w}_{t}$ is the weighted average wage level of stayers and movers. A similar decomposition is used by Hahn et al. (2018) for the U.S.

Figures 1 and 2 report the decomposition during the period 1999-2015 for Italy and 1996-2016 for France. Vertical lines in both countries represent the years immediately before a recession. First, nominal wage growth is always positive. This is not a surprising result as in both countries wages are determined by collective agreements which typically prevent nominal wage cuts, whereas firm level bargaining can only regulate additional pay components 4 Second, in both countries aggregate data show some cyclicality of wages, slightly more evident in Italy than in France. However, wage dynamics is largely influenced by people who stay in the same job. Net flows from and to non-employment tend to have a negative or null impact on wage growth suggesting that firms recompose their workforce in order to counterbalance the growth rate of nominal wages of stayers. Last, movers contribute positively to wage growth, but, differently from the U.S. their contribution is rather small, especially in France. In Italy the contribution of movers was around 40\% of total wage growth before the Great Recession and declined to almost zero during the prolonged recessionary period of 2009-2014. (These results are indeed rather similar to Hahn et al. (2017, 2018) for the US.)

\section{The composition channel: observed job-to-job transitions and wage growth of stayers and movers}

In this section we focus on workers who are employed at least for two consecutive years, and we study the dynamics of their probability of changing job and of their wages. To

\footnotetext{
${ }^{4}$ Using the DADS, Audenaert et al. (2014) shows that in France among full time workers from the private sector working for the same firm two consecutive years, $26 \%$ are subject to a wage cut.
} 
proxy local variations in economic conditions we rely on the unemployment rate where the job is located. Then we look at the probability of changing job, at the wage premium associated to a job change, and the sensitivity of movers' wages to changes in the local unemployment rate (relative to stayers' wages).

We match our employer-employee data with the LFS local unemployment rate (110 provinces in Italy, 94 departments in France) $5^{5}$ The final sample consists of almost 8 million observations in Italy and 6 in France.

We estimate the following two basic equations:

$$
\begin{gathered}
\text { mover }_{i j t}=\gamma_{1} U_{l t}+\gamma_{2} x_{i j t}+\theta_{l}+\mu_{i}+\xi_{t}+\kappa_{s}+\eta_{i j t} \\
\Delta \ln \left(w_{i j t}\right)=\beta_{1} \text { mover }_{i t}+\beta_{2} U_{l t}+\beta_{3} U_{l t} * \text { mover }_{i t}+\beta_{4} x_{i j t}+\delta_{l}+\nu_{i}+\zeta_{t}+\lambda_{s}+\epsilon_{i j t}
\end{gathered}
$$

In Equation 1 the variable mover $_{i j t}$ is a dummy equal to 1 if worker $i$ employed in $t-1$ in firm $j$, changes firm between $t-1$ and $t$. The variable $U_{l t}$ is the employment rate at time $t$ of local labor market $l$ where firm $j$ is located. The matrix $x_{i j t}$ contains worker $i$ and firm $j$ time varying characteristics, like occupation, part-time regime, firm (log) average wage, (log) firm size, firm age and firm age square depending on the specification. All characteristics refer to year $t-1$. The variable $\theta_{l}, \nu_{i}, \kappa_{s}$ and $\zeta_{t}$ are local labor market, individual, sector and time fixed effects, respectively. The equation is estimated by a linear probability model.

In Equation 2 the dependent variable $\Delta \ln \left(w_{i j t}\right)$ is the difference between time $t$ and time $t-1$ of $\log$ nominal wages of worker $i$ employed in firm $j$ at $t-1$ and the dummy mover $_{i j t}$ is an independent variable. As in Equation 1, $x_{i j t}$ contains workers' and firms' time variant characteristics and we add local labor market, individual, sector and time fixed effects. In this specification the coefficient $\beta_{2}$ is the elasticity of wage growth with respect to deviations of the local unemployment rate from its long-term average. In both equations, standard errors are clustered by local labor market-year level to control for correlation of workers subject to common local shocks.

Equation 1 looks at composition effects of wage dynamics. Equation 2 instead captures the direct effect of local unemployment shocks on nominal daily wages and allows us to determine whether it is similar for stayers and movers. In these estimates we assume that the local conditions are captured by the local unemployment rate. One could argue that in both countries administrative provinces/departments are too large to capture local labor market conditions, being travel-to-work areas typically smaller than administrative provinces or departments. Our choice is motivated by the lack of data on the unemployment rate for smaller geographical areas for all the years here considered.

\footnotetext{
${ }^{5}$ Results are similar if we are using unemployment rate at a larger administrative level (regions). See in Appendix Tables B1 and B2
} 
Figures $3 \mathrm{a}$ and $4 \mathrm{a}$ shows that in both countries workers move more often during booms than during downturns, highlighting the cyclicality of job-to-job flows. Figures $11 \mathrm{~b}$ and $12 \mathrm{~b}$ reports wage changes for stayers and movers in France and Italy, respectively. The cyclicality of the wage premium of movers is less obvious at first sight. An interesting descriptive point is the reduction of this premium in Italy after the Great Recession.

Tables 2 and 3 report the estimates for France and Italy respectively. In both tables columns 1 and 2 refer to Equation 1, columns 3-8 to Equation 2. First, in both countries the probability of a job-to-job move is little correlated with the local unemployment rate. In Italy one standard deviation increase in the unemployment rate (equal to 5 percentage points, see Table 1) is associated with only a $0.6 \mathrm{pp}$ reduction in the probability of changing job (out of an average probability of moving of 10\%); in France the same increase in the unemployment rate implies a reduction in the probability of moving by $0.1 \mathrm{pp}$ (out of an average of $8 \%$ ) and the coefficient is not statistically significant. These effects are undoubtedly small.

Columns 3 and 4 of both Tables 2 and 3 (without and with individual fixed effects) show that, relative to stayers, wage growth of movers is higher, confirming the standard Burdett and Mortensen (1998) model ${ }^{6}$ For all workers, the wage premium associated to moving strongly reacts to the local unemployment rate (Col. 5 and 6), as in a standard Phillips curve setting. If the unemployment rate increases by one standard deviation (5 pp), the wage premium associated to changing job is just $0.7 \mathrm{pp}$ lower in Italy and $0.6 \mathrm{pp}$ lower in France (relative to an average wage premium of about $1.3 \mathrm{pp}$ and 0.8 , respectively). Thus, movers affect wage dynamics mostly through the cyclicality of wage changes associated to job moves rather than through the pro-cyclicality of job-to-job moves themselves. In general, however, - give their small weight in the population — their contribution is rather small. Finally, wages of stayers respond very little to the local unemployment rate (Columns 6 and 8 of Tables 2 and 3 , with individual fixed effects). It is worth mentioning, however, that the estimated impact of the unemployment rate on the probability of moving is very much influenced by the cyclical indicator used Karahan et al., 2017 make a more general point on this topic). To show this point in Table B2 of Appendix 8 we report the same estimates of Table 3 for Italy where we include the regionlevel unemployment rate (for 20 regions) instead of the province-level one (for more than 100 provinces). Estimates refer only to Italy, because in France the local unemployment rate is not significantly related to the probability of moving (neither at the department level nor at the regional level). According to those estimates a $1.6 \mathrm{pp}$ increase in the unemployment rate (equal to one standard deviation of the regional unemployment rate) is associated to $0.1 \mathrm{pp}$ increase in the probability of moving. The effect is still rather small but is more than three times larger than the estimates based on the province-level unemployment rate.

\footnotetext{
${ }^{6}$ Figure 3 b shows that 2015 may be a particular year in the French data but the results are robust when we drop this year in estimations.
} 
As a further robustness check we exploit a characteristics of the Italian bargaining system; unfortunately, because of the lack of data the same exercise cannot be carried out for France. In Italy wage growth is partly determined by sector-level centralized collective agreements and partly by negotiation at the firm-level, between the firm and the worker, or decentralized collective agreements (mainly in larger firms). The latter part of wage growth can also include variable wage components, like bonuses. For almost all workers in our sample we know what is the reference collective agreement and, using aggregate Istat data on negotiated wages, we can calculate: (i) how much of the observed wage growth can be attributed to collective agreements and (ii) how much is specific to the workerfirm match. To build this variable we subtract to total daily wage growth the growth of negotiated wages referred to the collective contract the worker belonged to in $t-1$. We then look at the dynamics of the two components separately; the results are reported in Table 4. First, we find that the part of wage growth which is bargained at the central level does not seem to be highly correlated with the unemployment rate. As expected, the gain in contractual wages for those who move is null (since contractual wages are equal for everybody belonging to the same national contract). More importantly, the correlation of wage gains for movers to unemployment as well as the wage premium is entirely driven by the part of wage growth which is specific to the match (i.e. negotiated within the firm by workers or firm-level unions or due to variable wage components). This robustness check allows us to qualify the wage dynamics we are analyzing, i.e. that it is it mostly specific to the match.

Appendix 8 tests the robustness of our results by reporting the exact same estimates on the sample of male permanent workers only.

\section{Heterogeneity by worker and firm characteristics}

\subsection{Worker occupation}

One of the results of the MPV theoretical framework is that firms compete for workers and are willing to increase their wages when they are more at risk of moving to another firm. An implicit assumption in this setting is that workers cannot be easily substituted at low costs. On a similar ground MPV (2018) show that in a model with on-the-job search heterogeneous human capital and human capital depreciation during unemployment, firms tend to prefer poaching from other firms than hiring from unemployment. Consequently, gains from moving are higher for high-skilled workers as they are more often poached by other firms. To test for this hypothesis we split our samples into two groups of workers, according to the skill-content of their occupation. One group is composed of blue-collar workers, clerks and other low-skilled occupations in the service sector. The other group is composed of high-skilled white-collars and managers. Workers' type of occupation is 
observed at time $t-1.7$

Figures 5 and 6 report the share of a job-to-job move in total employment for both highand low-skilled (left-hand panel) and the associated wage change (right-hand) for France and Italy respectively. In both countries the probability of moving is higher for low-skilled occupations, but the associated wage change is smaller than for high-skilled occupations. The correlation of wages with shocks seems instead rather similar among groups. The higher probability to record a job-to-job transition for low-skilled occupations, associated to lower wage increases, suggests that these flows are probably generated by a separation and a subsequent new job, instead of a genuine job-to-job transition.

We investigate the reaction of these flows to changes in the unemployment rate by estimating Equations (1) and (2) separately the two groups of workers. Columns [1] and [2] for France and columns [5] and [6] simply relate job-to job flows to the evolution of the unemployment rate by type of worker. The other columns compare wage changes of movers with those of stayers, by type of workers. First, at least in in Italy, the probability of moving is highly correlated to the local unemployment rate for low-skilled workers. Second, wage gains from moving are always positive and are remarkably larger for high-skilled workers as suggested by 5 and 6 . They decline, however, the larger the local unemployment rate.

\subsection{Type of worker contract}

One of the key features of the French and the Italian labor markets is the so-called dualism, i.e. the existence of two types of job contracts: open-ended and fixed-term. The first is a standard job contract with no fixed-term clause, highly protected in both countries. The second has a limited duration and low termination costs (no cost in Italy). The regulation of temporary contracts follows similar guidelines in the two countries.

Workers hired with a temporary job contract are naturally forced to look for another job when their contract expires. Compared with permanent workers their bargaining power is then lower as they are more at risk of becoming unemployed. The correlation between wage dynamics and unemployment rate can then differ from that of permanent workers. For this reason we split our sample into permanent and temporary workers and carry out the same exercise as in Equations 1 and 2 .

To better interpret our findings it is important to take into account that in our sample we are considering only temporary workers who have relatively long contracts, as they must be working for two consecutive years. We are excluding very short contracts which are more likely to be particularly sensitive to economic shocks. Nevertheless, in Italy the large part of job-to-job flows can be attributed to temporary workers (Figure 8a: left hand panel) but their wage gain from moving is smaller than the one obtained by permanent workers

\footnotetext{
${ }^{7}$ Education or detailed occupations are not available.
} 
(right-hand side). In France the contribution of flows of fixed-term contracts is smaller than in Italy (Figure 7a) and the wage gains of moving are relatively similar whatever the contract type.

Table 6 reports the estimates of the probability of moving and wage growth by type of contract. In both countries the probability of moving is more sensitive to local unemployment shocks for temporary workers. Moreover, in both countries job-to-job transitions of temporary workers are not associated to a wage increase, whereas those of permanent workers are. Additionally, high values of unemployment usually lead to a larger drop in the wage premium associated to moving for permanent workers.

\subsection{Firm size and age}

The dynamics of workers flows up to the job ladder can potentially affect not only workers' earnings and inequality (e.g. Card et al., 2015, Fallick et al., 2012), but also productivity dynamics. As far as highly productive firms are also the larger ones, job-to-job moves by firm size have received attention too (e.g. Haltiwanger et al., 2018).

MPV (2012) show that during recessions small firms can poach highly productive workers from larger firms, because there is less competition for workers. However, Haltiwanger et al. (2018) find that in the U.S. workers tend to move from large to small firms. In particular, small young and dynamic firms attract already employed workers to expand their size. These moves are also highly procyclical.

We then look at moves by firm size and firm age to assess what is the prevalent driver of the observed wage growth in France and Italy. We classify a firm as large if its size exceeds 50 employees 8 Size is defined at time $t$ and corresponds to the size of the movers' destination firm. Based on the results of the previous sections, we focus on the correlation between local shocks and our variables of interest-the probability of moving and the associated wage growth. Results are reported in Table 7 .

In both France and Italy small firms attract more inflows than larger ones (Figures 9a and 10a). The wage gain associated to a move, however, is much smaller in small firms (see also Table 7): in Italy it almost doubles for movers in very large firms (being equal to 3.8 per cent, Table 7). Moreover, it seems to be more correlated with the local unemployment rate for larger firms particularly in France, consistently with MPV (2018) (Table 7).

This evidence implies that large firms drive movers' wage growth especially during expansions as their probability to attract workers increases (in relative terms) and the associated wage gain (calculated at average unemployment rate) is remarkably higher than the average. In Italy, however, larger firms, defined as those with size larger than the 50

\footnotetext{
${ }^{8}$ This is an important threshold in both countries.
} 
employees, employ only $25 \%$ of total permanent employment of which $10 \%$ are movers. This evidence implies that movers' wage dynamics in Italy is dampened by the rather low average firm size. On the contrary, firms are much larger in France where more than $10 \%$ of firm population and hire almost two third of the private sector employees. Consequently, in France movers' wage dynamics is mainly driven by those large firms.

Size however is not the only firm characteristic which can affect job-to-job flows. In particular, Fort et al. (2013) and Haltiwanger et al. (2018) show that size growth and poaching depend on the firm life-cycle. In the U.S. newly-born firms highly contribute to job-to-job flows, whereas the contribution of older firms is relatively negligible, as they shrink before exiting the market. To check for this issue Table 8 reports the estimates of the standard Equations (1) and (2) for younger firms (defined as those with age lower than the $25^{\text {th }}$ percentile) and older firms (those with age higher than the $75^{\text {th }}$ percentile). We then look also at young and small firms (size smaller than 50 employees). The upper part of the table refers to France, the bottom to Italy.

Figures 11a and 12a indicate that job-to-job flows into a young firm are larger than in other firms. Table 8 shows that the probability of moving to older firms displays little cyclicality; that of moving in a young firm is instead slightly correlated with local shocks, especially in Italy: in this country one standard deviation of the local unemployment rate implies a decline by $0.8 \mathrm{pp}$ in the probability of moving with respect to an old firm (a remarkably larger effect if compared with the average). Concerning wage changes, in France the gain from moving to a young firm is related to local unemployment rate, compared to old firms where the wage premium is not significant. In Italy wage gains for movers are more related to shocks in the local unemployment rate in small firms.

Columns [3] and [6] of Table 8 focus only on young firms at the beginning of their life-cycle, when they are also small. The results confirm that in Italy flows into a smallyoung firm are higher than the average and more correlated to local shocks. According to the results displayed for both countries, wage gains in small-young firms are slightly lower than the average. In Italy gains from moving in a small-young firm are positive, and negatively correlated to local shocks to the unemployment rate whereas in France wages of both stayers and movers towards young firms are sensitive to local unemployment.

The combined evidence presented in Tables 7 and 8 suggests that small and young firms are net attractors of movers, slightly more when unemployment is low. The wage gain they offer, however, is lower than the average firm, and more related to local unemployment rate, at least in Italy. Thus, we conclude that any factor that limits worker flows towards large firms, or hampers wage growth in smaller ones (e.g. credit constraints) negatively affects also observed aggregate wage growth. 


\section{The strategic effect: the impact of job-to-job flows on stay- ers' wages}

In the previous sections we have showed that job-to-job flows in France and Italy responds to changes in local labor market conditions, in line with what suggested by the theory and found by empirical research on the U.S.. However, the contribution of movers to total wage growth is rather small and wage dynamics are mainly determined by stayers.

As pointed out by MPV (2017b), job-to-job flows can affect aggregate wages not only because of a composition effect, like the one described in the previous sections, but also because of what they call a strategic effect. When labor demand increases, employed workers face more opportunities to change their job. As their outside option increases also their wage increases, because firms try to retain them.

MPV (2016a) make a step forward and present a model in which also stayers' wages respond directly only to job-to-job flows (when minimum wages or reservation wages are binding). Karahan et al. (2017) and MPV (2017b) test empirically this result by including proxies of job-to-job flows and flows into and out of employment in a standard wage growth regression. They find that job-to-job flows are the only variable affecting nominal wage growth whereas after controlling for job-to-job flows, unemployment-related measures do not matter.

We adopt their strategy and carry out the same test for France and Italy. Following in particular MPV (2017b) we identify different types of workers $y$, based on the full interaction of the following characteristics: province/department where individuals work at time $t-19$ gender, age group (three brackets) and workers in low-skilled occupations. Thus, using the full sample (i.e. including also entrants and exiters) for each type of workers we estimate the probability of being mover, an exiter or entrant for each type $y$ over time, controlling for individual and firm characteristics in $t-1$-sector, full-time, occupation level, log of the firm size and log of the average wage of the firm. In particular, we estimate the following equation:

$$
\text { status }_{i j y t}=\beta x_{i j t}+\theta_{s}+\theta_{y t}+u_{i j y t}
$$

where status $_{i j y t}$ is a dummy indicating whether worker $i$, working in firm $j$ in $t-1$ and belonging to type $y$, is a mover (or an entrant or a exiter) between $t$ and $t-1 ; x_{i j t}$ are controls for worker and firm characteristics evaluated at time $t-1$ and $\theta_{s}$ are sector fixed effects. $\theta_{y t}$, the worker-type fixed effect interacted with time dummies, is our proxy for the expected probability of a given transition for individuals of type $y$.

We name these type-specific time varying probabilities as follows: (i) EE for job-to-job

\footnotetext{
${ }^{9}$ It is measured at time $t$ for the entrants.
} 
transitions $\left(E E_{y t}\right)$; (ii) $\mathrm{EN}$ for flows towards non-employment $\left(E N_{y t}\right)$ and (iii) NE for flows from non-employment into employment $\left(N E_{y t}\right)$ and we assign each variables to each individual, according to her own type $y$.

We then run the following regression:

$$
\Delta \ln \left(w_{i y t}\right)=\beta_{1} \text { mover }_{i t}+\beta_{2} U_{y t}+\beta_{3} E E_{y t}+\beta_{4} E N_{y t}+\beta_{5} N E_{y t}+\beta_{6} z_{i y t} \gamma_{y}+\zeta_{t}+\epsilon_{i y t}
$$

where $y$ indicates the type of the workers. The dummy mover ${ }_{i t}$ is defined as in Equations (1) and (2) and $z_{i y t}$ are workers' and firms' characteristics. Here, differently from the other equations, $U_{y t}$ is the unemployment rate of worker-type $y$ estimated using LFS, i.e. the unemployment rate for each type of worker in a given province/department. Comparable data for workers types are available only after 2003. $E E_{y t}, E N_{y t}$ and $N E_{y t}$ are the time-varying fixed effects for each transition estimated above. Last, $\gamma_{y}$ and $\zeta_{t}$ are type and time fixed effects. Differently from Equation (2), Equation (4) then includes not only the unemployment rate $U_{y t}$ but also flows into and out of employment which obviously correlate with $U_{y t}$ and $E E_{y t}$ flows. In this case $U_{y t}$ captures determinants of the cyclicality of unemployment different from the ones already captured by flows into and out of employment (due for instance to flows in and out of participation). To appreciate how much $E N_{y t}$ and $N E_{y t}$ map into $U_{y t}$ Table 10 reports the cross-correlations among the three variables. As expected, the correlation between $U_{y t}$ and $E N_{y t}$ is negative whereas the one with $N E_{y t}$ is positive. This suggests that the in both countries the participation margin, i.e. flows of people who move to/from non-private employment, does not perfectly map into the unemployment rate.

The results of the estimates of Equation (4) are reported in Tables 11 and 12 for France and Italy, respectively. Columns 1-4 of both tables refer to the whole sample of stayers and movers, column 5 to movers only whereas column 6 to stayers only.

As in Tables 2 and 3 , we find that wage changes are larger for movers than for stayers. More importantly we find that EE flows are positively correlated to wage growth whereas EN flows have a negative correlation. Last, NE flows, which capture an increase in opportunities for non-employed workers tend to be positively correlated to wage growth. The same conclusions hold for the sub-sample of movers and stayers. Interestingly, larger EE flows affect not only wages of movers, but also wages of stayers. In particular, we find that a 1 standard deviation increase in the EE flows (equal to 2.8 pp in Italy an 2.1 pp in France, see Table 9 implies an increase in overall wage growth (of both stayers and movers) of about $0.14 \mathrm{pp}$ in Italy and $0.20 \mathrm{pp}$ in France. Focusing only in movers, wages increase by $0.39 \mathrm{pp}$ in Italy and $0.48 \mathrm{pp}$ in France, which is the direct effect of job-to-job moves. The indirect effect, i.e. the increase of wages of stayers, is significant in both countries: $0.05 \mathrm{pp}$ in Italy and 0.17 in France. These results are in line with the findings of MPV (2017b) for the US and outline the importance of EE flows in wage determination of stayers. 
Last, in all the specifications the magnitude of the coefficients of U, NE and EN flows are only slightly affected by the inclusion of EE flows (as shown by col. 4). In particular, a 1 standard deviation increase in the EN flows (equal to $6.4 \mathrm{pp}$ in Italy and 5.8 in France, see Table 9 implies a reduction in overall wage growth (of both stayers and movers) of about $0.17 \mathrm{pp}$ in Italy an no significant change in France; a 1 standard deviation increase in the NE flows (equal to $7.4 \mathrm{pp}$ in Italy and $7.3 \mathrm{pp}$ in France) implies an increase in overall wage growth (of both stayers and movers) of about $0.30 \mathrm{pp}$ in both countries. This result differs from the one of MPV (2017b) and Karahan et al. (2017), suggesting that in France and Italy the risk of unemployment affects wage growth.

\section{Conclusions}

In this paper we analyze how job-to-job flows impact the dynamics of aggregate wages in Italy and France. We use administrative microdata and look at two channels: a composition effect, due to the positive correlation of job-to-job flows and local shocks, and a strategic effect, determined by the response of wages of stayers to the option of moving. We detect the presence of both these effects in France and Italy.

Differently from the U.S., however, we find that the probability of moving is rather low and displays very little cyclicality in these euro area countries, characterized by more rigid and less mobile labor markets. Probably for this reason, job-to-job flows are less able to explain wage dynamics in France and Italy than in the US, while flows from and to employment, related to local changes in the unemployment rate, still affect wage growth of both stayers and movers. This result calls further research on the competition of employed and unemployed workers for jobs, that in turn may depend on some structural characteristics of jobs, wages and firms. 


\section{References}

Audenaert, D., J. Bardaji, R. Lardeux, M. Orand, and M. Sicsic (2014), "Wage resilience in france since the great recession." INSEE working paper.

Burdett, K. and D. T. Mortensen (1998), "Wage differentials, employer size, and unemployment." International Economic Review, 39, 257-73.

Card, D., J. Heining, and P. Klein (2015), "Workplace heterogeneity and the rise of west german wage inequality." Quarterly Journal of Economics, 128(3), 967-1015.

Carneiro, A., P. Guimaraes, and P. Portugal (2012), "Real wages and the business cycle: Accounting for worker, firm, and job title heterogeneity." American Economic Journal: Macroeconomics, 4, 133-152.

Fallick, B., Haltiwanger J., and McEntarfer E. (2012), "Job-to-job flows and the consequences of job separations." S. Federal Reserve Board Finance and Economics Discussion Series Paper \#2012-73.

Fort, T.C., J. Haltiwanger, R.S. Jarmin, and Miranda J. (2013), "How firms respond to business cycles: The role of firm age and firm size." IMF Economic Review, 61, 520-559.

Gertler, M. and S. Gilchrist (1994), "Monetary policy, business cycles, and the behavior of small manufacturing firms." Quarterly Journal of Economics, 2, 309-340.

Hahn, Joyce K., Henry R. Hyatt, and Hubert P. Janicki (2018), "Job ladders and growth in earnings, hours, wages." Working paper.

Hahn, Joyce K., Henry R. Hyatt, Hubert P. Janicki, and Stephen R. Tibbets (2017), "Jobto-Job Flows and Earnings Growth." American Economic Review, 107, 358-363.

Haltiwanger, J., H. Hyatt, and E. McEntarfer (2018), "Who moves up the job ladder?" Journal of Labor Economics, 36, S301-S336.

Karahan, F., R. Michaels, Be. Pugsley, and A. Sahin (2017), "Do job-to-job transitions drive wage fluctuations over the business cycle?" American Economic Review: Papers Es Proceedings, 107, 353-357.

Margolis, D. (2002), "Licenciements collectifs et délais de reprise d'emploi." Economie et Statistiques, 351, 65-85.

Moscarini, G. and F. Postel-Vinay (2012), "The contribution of large and small employers to job creation in times of high and low unemployment." American Economic Review, 102, 2509-39.

Moscarini, G. and F. Postel-Vinay (2016a), "Wage posting and business cycles." American Economic Review: Papers $\&$ Proceedings, 106, 208-213. 
Moscarini, G. and F. Postel-Vinay (2016b), "Wage posting and business cycles: A quantitative exploration." Review of Economic Dynamics, 19, 135-160.

Moscarini, G. and F. Postel-Vinay (2016c), "Did the job ladder fail during the great recession?" Journal of Labor Economics, 34(S1), S55-S93.

Moscarini, G. and F. Postel-Vinay (2017a), "The cyclical job ladder." Working paper.

Moscarini, G. and F. Postel-Vinay (2017b), "The relative power of employment-toemployment reallocation and unemployment exits in predicting wage growth." American Economic Review: Papers $\& 3$ Proceedings, 107, 364-368.

Moscarini, G. and F. Postel-Vinay (2018), "On the job search and the business cycle." Working paper.

Picart, C. (2007), "Flux d'emploi et de main d'oeuvre en france : un réexamen." INSEE working paper.

Pissarides, Christopher A. (2009), "The Unemployment Volatility Puzzle: Is Wage Stickiness the Answer?" Econometrica, 77, 1339-1369.

Sharpe, S. A. (1994), "Financial market imperfections, firm leverage, and the cyclicality of employment." American Economic Review, 84, 1060-1074.

Shin, D. and G. Solon (2007), "New evidence on real wage cyclicality within employeremployee matches." Scottish Journal of Political Economy, 54, 648-660. 


\section{Figures}

Figure 1 - France: Decomposition of wage growth by type of flows

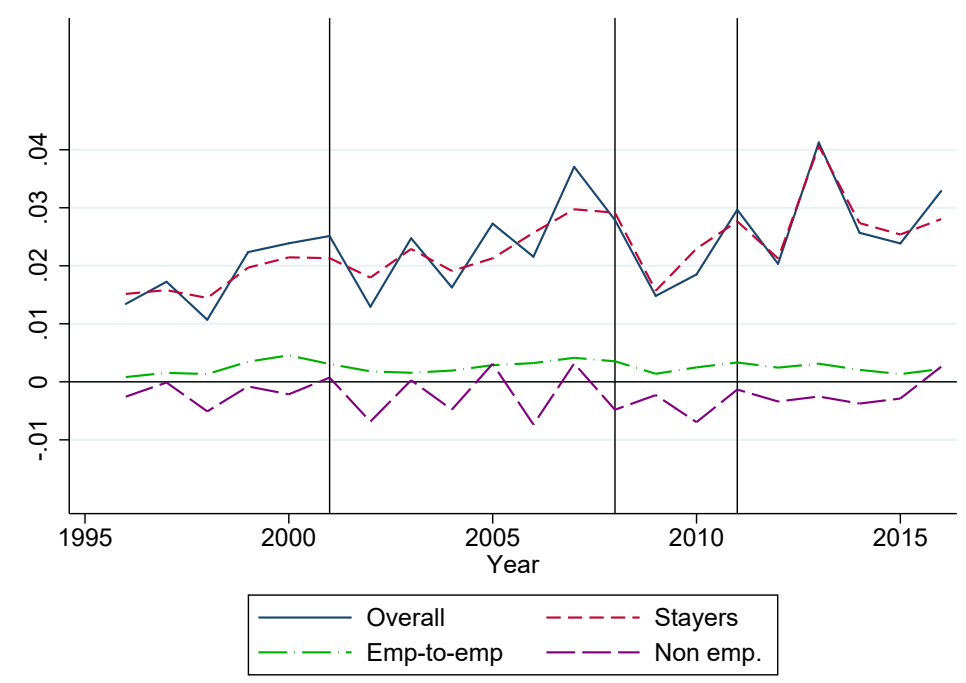

Note: Source: DADS, employees in the private sector aged 25-50. Average annual changes. The graph displays how much of the aggregate age dynamics (Overall) is driven by movers, stayers and entry and exit in the labor market. See equation 1 for details. Grey lines refer to recessions.

Figure 2 - Italy: Decomposition of wage growth by type of flows

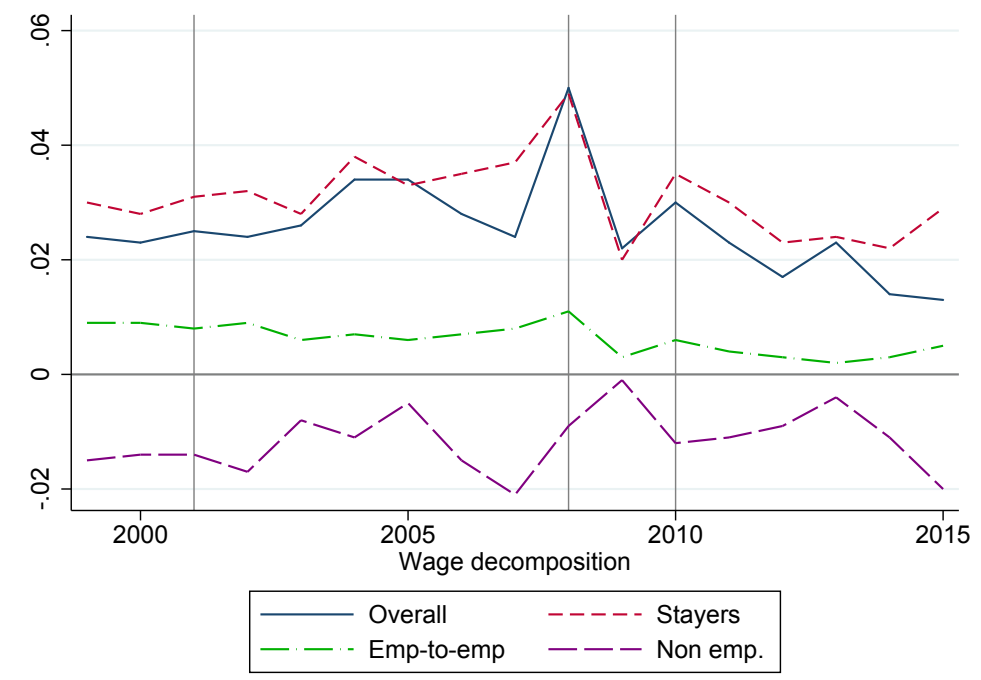

Note: Source: INPS, employees in the private sector aged 25-50. Average annual changes. The graph displays how much of the aggregate age dynamics (Overall) is driven by movers, stayers and entry and exit in the labor market. See equation 1 for details. Grey lines refer to recessions. 
Figure 3 - France: Share of job-to-job movers and wage premium
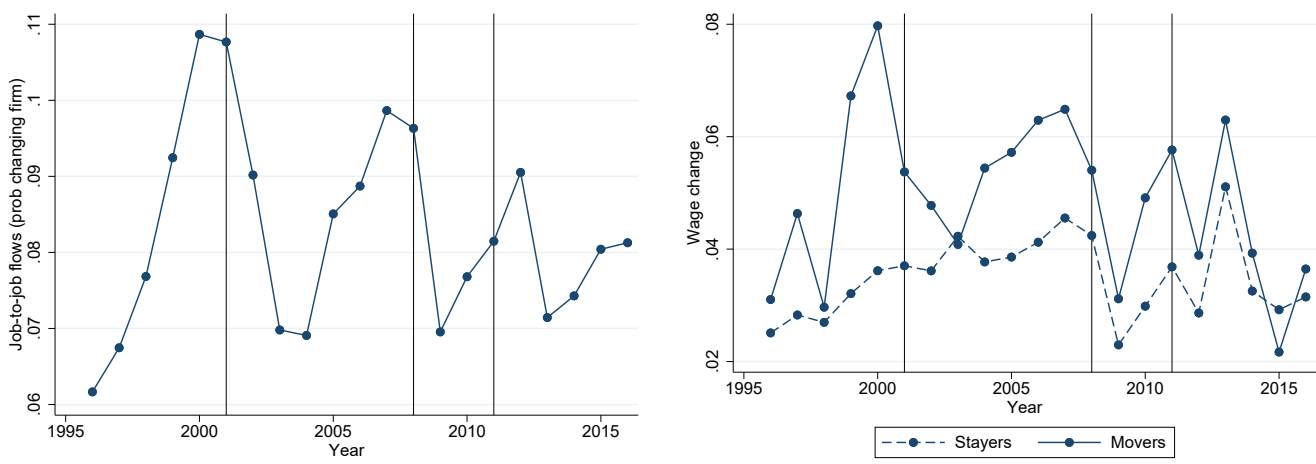

Note: Source: DADS. The graph displays the share of job-to-job movers among employees in the private sector aged 25-50. Movers are computed as those who are employed in December each year, but in two different firms, with a non-employment spell within the year of less than one month. Wage change is the change in daily wage in two consecutive years for individuals who are employed both years, in the same firm (stayers) or in two different firms (movers). Grey lines refer to recessions.

Figure 4 - Italy: Share of job-to-job movers and wage premium
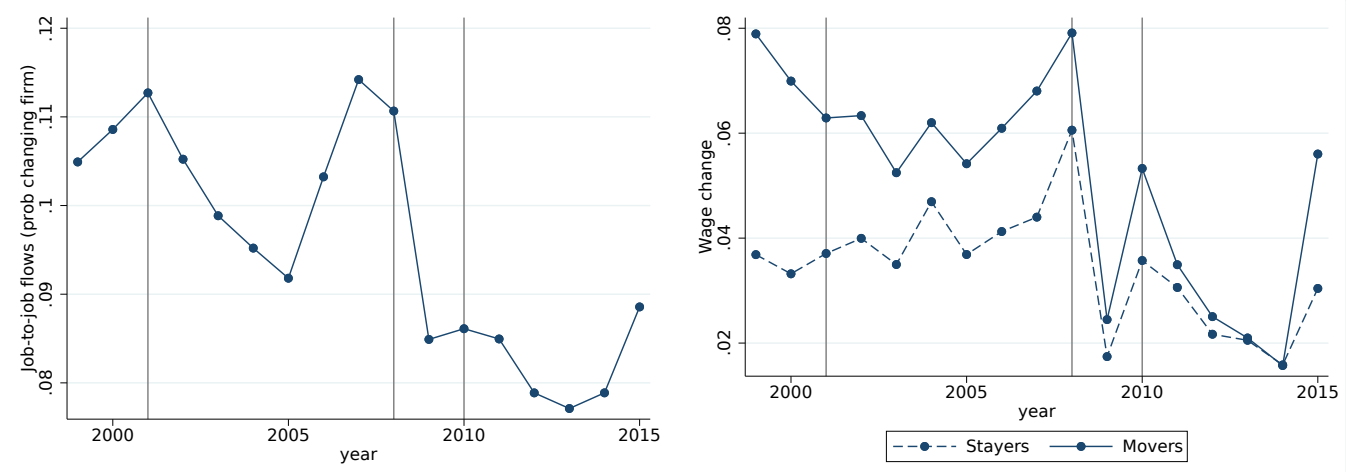

Note: Source: INPS. The graph displays the share of job-to-job movers among employees in the private sector aged 25-50. Movers are computed as those who are employed in December each year, but in two different firms, with a non-employment spell within the year of less than one month. Wage change is the change in daily wage in two consecutive years for individuals who are employed both years, in the same firm (stayers) or in two different firms (movers). Grey lines refer to recessions. 
Figure 5 - France: Share of job-to-job movers and wage premium low- and high-skilled workers
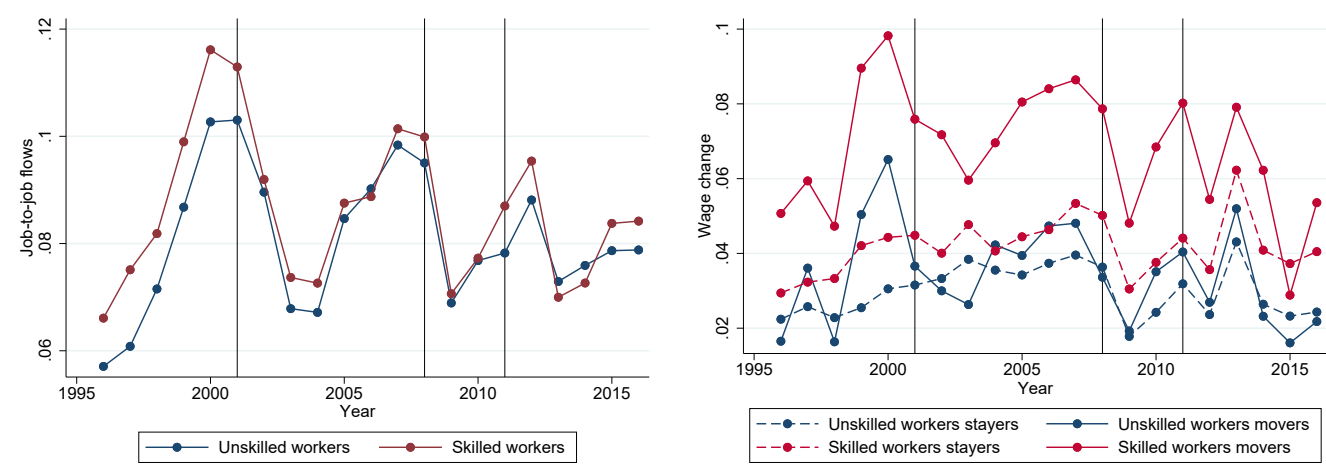

Note: Source: DADS. Low-skilled workers are those classified as blue-collars, clerks, employees in trade or in services for the households. Grey lines refer to recessions.

Figure 6 - Italy: Share of job-to-job movers and wage premium low- and high-skilled workers
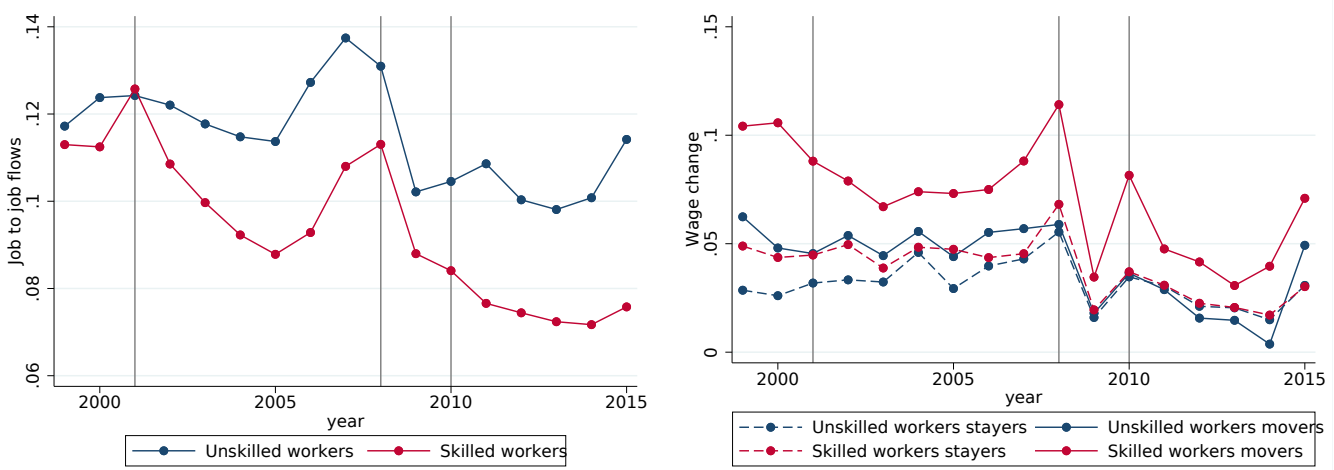

Note: Source: INPS. Low-skilled workers are those classified by INPS as blue-collars or apprentices. Grey lines refer to recessions.

Figure 7 - France: Share of job-to-job movers and wage premium temporary and permanent workers
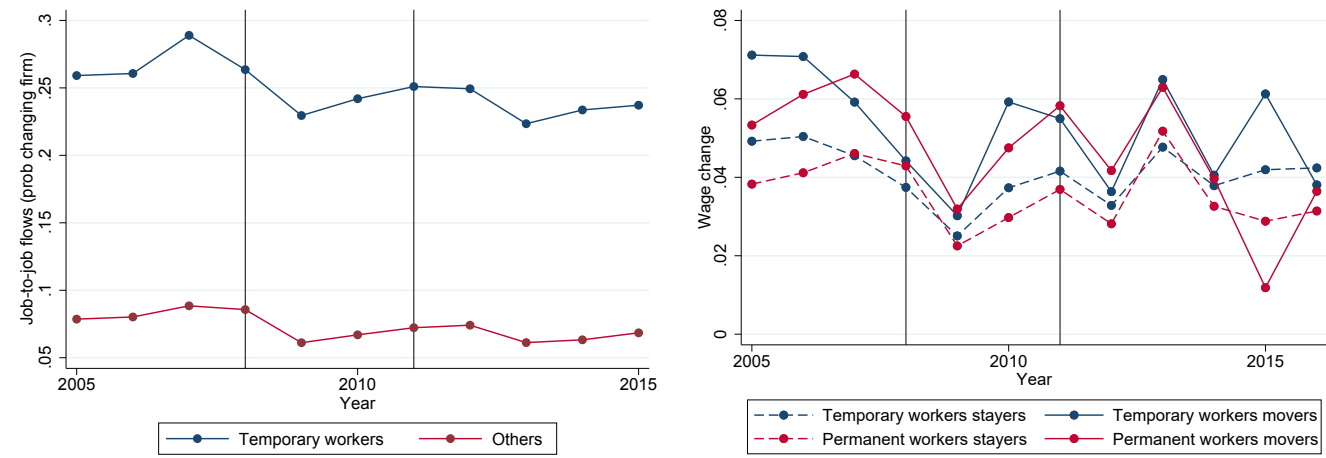

Note: Source: DADS. Grey lines refer to recessions. Labor contract is only available since 2005. 
Figure 8 - Italy: Share of job-to-job movers and wage premium temporary and permanent workers
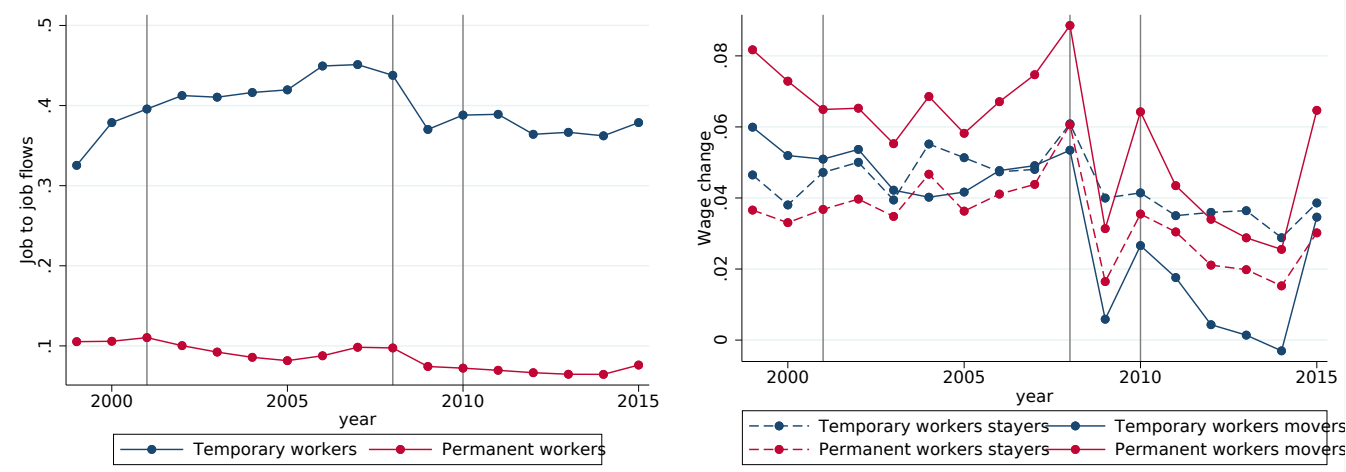

Note: Source: INPS. Grey lines refer to recessions.

Figure 9 - France: Share of job-to-job movers and wage premium in small firms
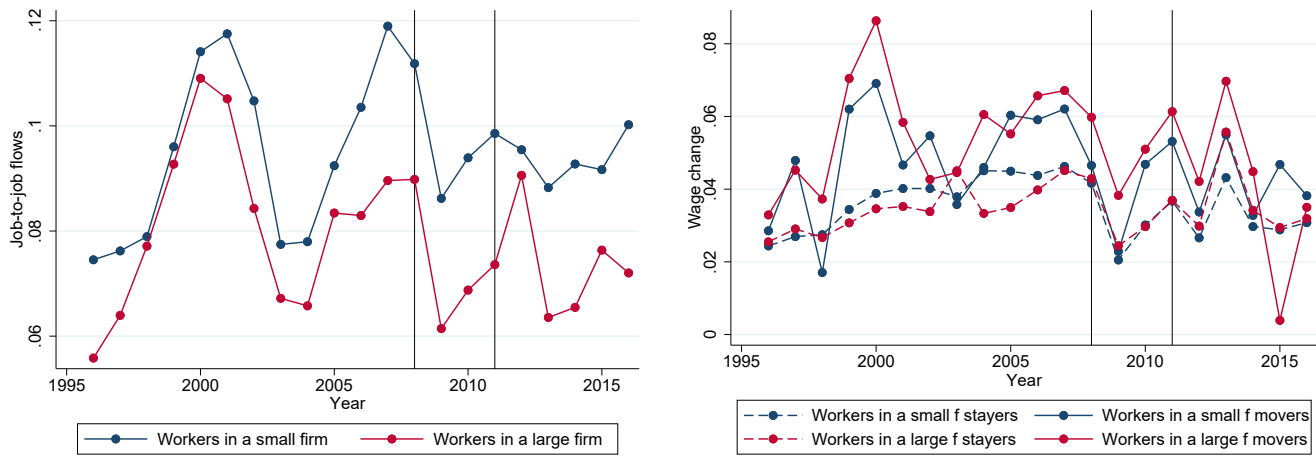

Note: Source: DADS. Grey lines refer to recessions. Small if firm size is below the 50 employees.

Figure 10 - Italy: Share of job-to-job movers and wage premium in small firms
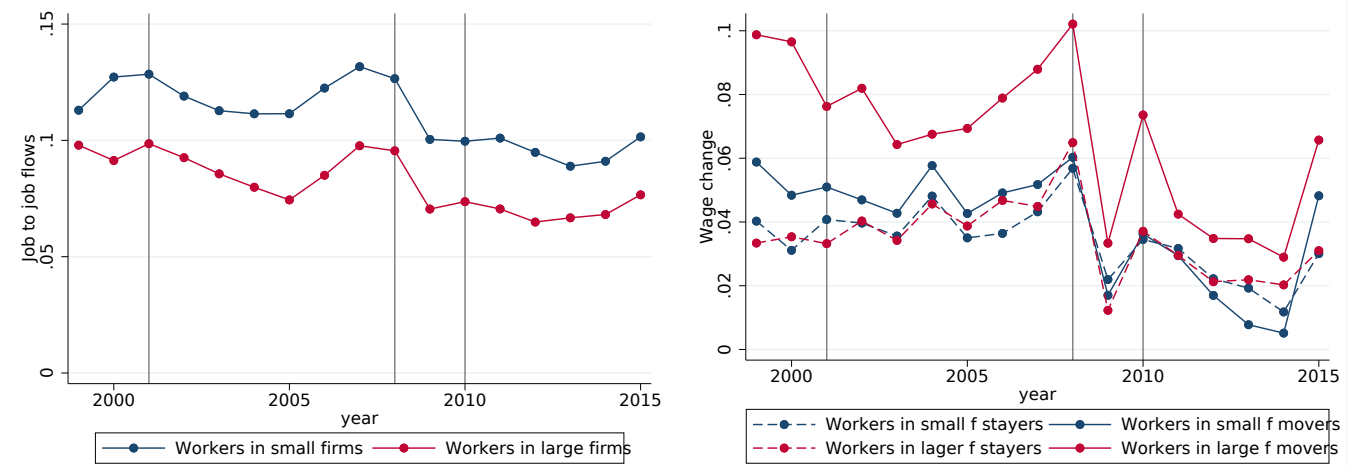

Note: Source: INPS. Grey lines refer to recessions. Small if firm size is below the 50 employees. 
Figure 11 - France: Share of job-to-job movers and wage premium in young firms
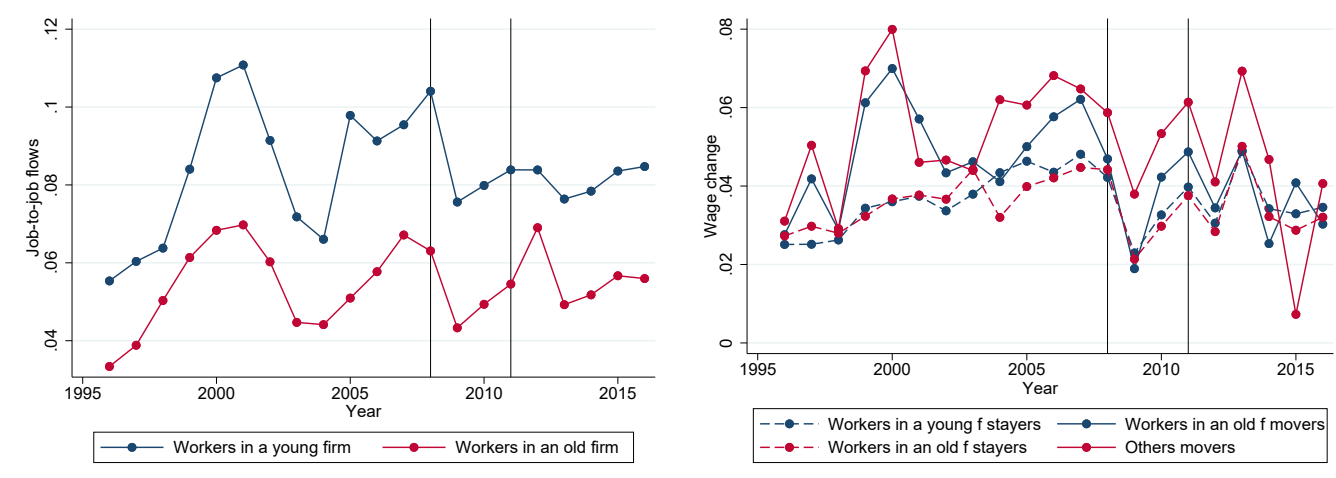

Note: Source: DADS. Grey lines refer to recessions. Young if firm age is below the 25th percentile of the distribution.

Figure 12 - Italy: Share of job-to-job movers and wage premium in young firms
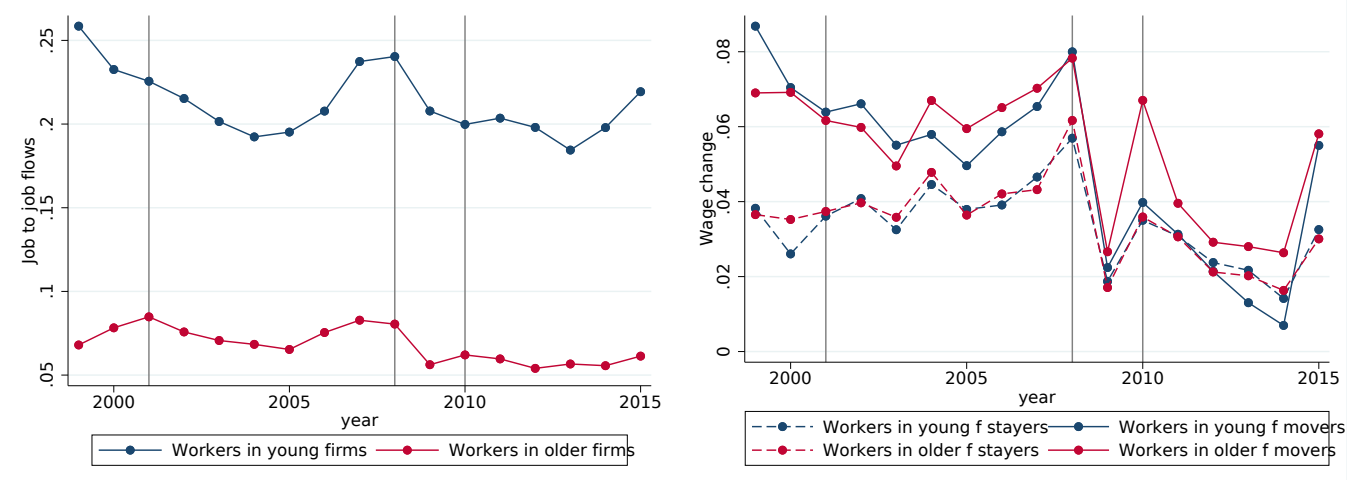

Note: Source: INPS. Grey lines refer to recessions. Young if firm age is below the 25th percentile of the distribution. 


\section{Tables}

Table 1 - Summary statistics

\begin{tabular}{|c|c|c|c|c|c|c|}
\hline & \multicolumn{3}{|c|}{ Italy } & \multicolumn{3}{|c|}{ France } \\
\hline & $\begin{array}{l}\text { All } \\
(1)\end{array}$ & $\begin{array}{l}\text { Stayers } \\
(2)\end{array}$ & $\begin{array}{l}\text { Movers } \\
\text { (3) }\end{array}$ & $\begin{array}{l}\text { All } \\
(4)\end{array}$ & $\begin{array}{l}\text { Stayers } \\
(5)\end{array}$ & $\begin{array}{c}\text { Movers } \\
(6)\end{array}$ \\
\hline Movers (as \% of total empl.) & 0.102 & & & 0.084 & & \\
\hline Movers (as \% of total hires) & 0.426 & & & 0.293 & & \\
\hline Daily wage & $\begin{array}{c}80.382 \\
(50.660)\end{array}$ & $\begin{array}{c}80.822 \\
(50.720)\end{array}$ & $\begin{array}{c}76.061 \\
(49.966)\end{array}$ & $\begin{array}{c}80.142 \\
(58.309)\end{array}$ & $\begin{array}{c}80.361 \\
(58.579)\end{array}$ & $\begin{array}{c}77.765 \\
(55.224)\end{array}$ \\
\hline Log wage change & $\begin{array}{c}0.036 \\
(0.149)\end{array}$ & $\begin{array}{c}0.034 \\
(0.134)\end{array}$ & $\begin{array}{c}0.054 \\
(0.240)\end{array}$ & $\begin{array}{c}0.038 \\
(0.174)\end{array}$ & $\begin{array}{c}0.037 \\
(0.161)\end{array}$ & $\begin{array}{c}0.049 \\
(0.283)\end{array}$ \\
\hline $\begin{array}{l}\text { Days worked } \\
\text { (current spell) }\end{array}$ & $\begin{array}{l}272.770 \\
(73.451)\end{array}$ & $\begin{array}{l}284.865 \\
(59.578)\end{array}$ & $\begin{array}{l}166.592 \\
(95.075)\end{array}$ & & & \\
\hline $\begin{array}{l}\text { Days paid } \\
\text { (current spell) }\end{array}$ & & & & $\begin{array}{l}344.250 \\
(59.630)\end{array}$ & $\begin{array}{l}355.349 \\
(33.326)\end{array}$ & $\begin{array}{c}223.462 \\
(119.311)\end{array}$ \\
\hline Female & 0.349 & 0.352 & 0.319 & 0.372 & 0.375 & 0.349 \\
\hline Age & $\begin{array}{l}38.069 \\
(6.846)\end{array}$ & $\begin{array}{l}38.214 \\
(6.828)\end{array}$ & $\begin{array}{l}36.797 \\
(6.872)\end{array}$ & $\begin{array}{l}38.474 \\
(6.829)\end{array}$ & $\begin{array}{l}38.643 \\
(6.807)\end{array}$ & $\begin{array}{l}36.637 \\
(6.799)\end{array}$ \\
\hline Temporary contract & 0.058 & 0.037 & 0.245 & 0.048 & 0.036 & 0.222 \\
\hline Full time & 0.846 & 0.846 & 0.845 & 0.867 & 0.868 & 0.832 \\
\hline Low-skilled workers & 0.589 & 0.583 & 0.640 & 0.599 & 0.601 & 0.593 \\
\hline Firm average wage (log) & $\begin{array}{c}7.479 \\
(0.472)\end{array}$ & $\begin{array}{l}7.488 \\
(0.465)\end{array}$ & $\begin{array}{c}7.393 \\
(0.517)\end{array}$ & $\begin{array}{l}10.187 \\
(0.530)\end{array}$ & $\begin{array}{l}10.189 \\
(0.497)\end{array}$ & $\begin{array}{l}10.320 \\
(0.947)\end{array}$ \\
\hline Firm size (log) & $\begin{array}{c}4.333 \\
(2.637)\end{array}$ & $\begin{array}{c}4.349 \\
(2.635)\end{array}$ & $\begin{array}{c}4.187 \\
(2.655)\end{array}$ & $\begin{array}{c}5.132 \\
(2.866)\end{array}$ & $\begin{array}{c}5.151 \\
(2.876)\end{array}$ & $\begin{array}{c}4.925 \\
(2.734)\end{array}$ \\
\hline Firm age (years) & $\begin{array}{c}17.545 \\
(13.342)\end{array}$ & $\begin{array}{c}18.360 \\
(13.216)\end{array}$ & $\begin{array}{c}10.393 \\
(12.263)\end{array}$ & $\begin{array}{c}24.952 \\
(21.142)\end{array}$ & $\begin{array}{c}25.497 \\
(21.140)\end{array}$ & $\begin{array}{c}21.470 \\
(19.280)\end{array}$ \\
\hline $\begin{array}{l}\text { Share firms }>50 \text { employees } \\
\text { (in the sample) }\end{array}$ & 0.493 & 0.495 & 0.479 & 0.607 & 0.609 & 0.584 \\
\hline $\begin{array}{l}\text { Share firms }>50 \text { employees } \\
\text { (in the firm population) }\end{array}$ & 0.016 & & & 0.207 & & \\
\hline Local unempl. rate & $\begin{array}{c}0.073 \\
(0.048)\end{array}$ & $\begin{array}{c}0.074 \\
(0.048)\end{array}$ & $\begin{array}{c}0.069 \\
(0.045)\end{array}$ & $\begin{array}{c}0.088 \\
(0.027)\end{array}$ & $\begin{array}{c}0.089 \\
(0.027)\end{array}$ & $\begin{array}{c}0.087 \\
(0.026)\end{array}$ \\
\hline Observations & 7718759 & 6929419 & 789340 & 5993166 & 5488807 & 504359 \\
\hline
\end{tabular}

Note: Sources: INPS and DADS. Standard deviations within brackets. For movers: workers' and firms' characteristics observed before moving. Low-skilled workers in Italy are those classified by INPS as bluecollar workers; in France are those classified by Insee as employees and blue-collars. Share firms $>50$ employees refers to the share of workers working in firms with more than 50 employees. Because of data limitations, we use province-level unemployment rates for Italy and department-level unemployment rates for France. Contract type is only available after 2005 for France. 
Table 2 - Composition channel and job-to-job moves and wage changes. France

\begin{tabular}{lcccccccc}
\hline \hline & prob. moving & \multicolumn{7}{c}{ delta log wage } \\
& {$[1]$} & {$[2]$} & {$[3]$} & {$[4]$} & {$[5]$} & {$[6]$} & {$[7]$} & {$[8]$} \\
\hline mover & & & $0.010^{* * *}$ & $0.008^{* * *}$ & & & $0.018^{* * *}$ & $0.018^{* * *}$ \\
& & & $(0.001)$ & $(0.001)$ & & & $(0.003)$ & $(0.003)$ \\
unempl & -0.031 & -0.011 & & & $-0.022^{* *}$ & $-0.012^{*}$ & $-0.014^{*}$ & -0.003 \\
& $(0.019)$ & $(0.009)$ & & & $(0.009)$ & $(0.005)$ & $(0.007)$ & $(0.005)$ \\
unempl*mov & & & & & & & $-0.095^{* * *}$ & $-0.119^{* * *}$ \\
& & & & & & & $(0.035)$ & $(0.034)$ \\
$\mathrm{N}$ & 5787567 & 5781503 & 5787567 & 5781503 & 5787567 & 5781503 & 5856265 & 5856265 \\
\hline Ind. Fe & No & Yes & No & Yes & No & Yes & No & Yes \\
\hline
\end{tabular}

Note: Additional controls: gender, age, age squared, whether blue collar or white collar, whether full time, whether temporary, firm age, firm age squared, firm size, firm average wage, sector, year and local fixed-effects. All time-varying characteristics refer to $t-1$. Standard errors clustered at the local-year level. ${ }^{* * *}$ denotes significance at $1 \%,{ }^{* *}$ denotes significance at $2 \%,{ }^{*}$ denotes significance at $5 \%$.

Table 3 - Composition channel and job-to-job moves and wage changes. Italy

\begin{tabular}{lcccccccc}
\hline \hline & prob. moving & \multicolumn{7}{c}{ delta log wage } \\
& {$[1]$} & {$[2]$} & {$[3]$} & {$[4]$} & {$[5]$} & {$[6]$} & {$[7]$} & {$[8]$} \\
\hline mover & & & $0.016^{* * *}$ & $0.013^{* * *}$ & & & $0.026^{* * *}$ & $0.028^{* * *}$ \\
& & & $(0.001)$ & $(0.002)$ & & & $(0.002)$ & $(0.002)$ \\
unempl & $-0.088^{* * *}$ & $-0.135^{* * *}$ & & & -0.005 & -0.022 & 0.008 & 0.000 \\
& $(0.029)$ & $(0.031)$ & & & $(0.011)$ & $(0.012)$ & $(0.011)$ & $(0.012)$ \\
unempl*mover & & & & & & & $-0.137^{* * *}$ & $-0.150^{* * *}$ \\
& & & & & & & $(0.023)$ & $(0.028)$ \\
$\mathrm{N}$ & 8928603 & 8554455 & 7700989 & 7565255 & 7589479 & 7455608 & 7589479 & 7455608 \\
\hline Ind. Fe & No & Yes & No & Yes & No & Yes & No & Yes \\
\hline
\end{tabular}

Note: Additional controls: gender, age, age squared, occupation, log average wage at the firm level, log average firm size, firm's age, firm's age squared, sector, year and local fixed-effects. Standard errors clustered at the local-year level .*** denotes significance at $1 \%, * *$ denotes significance at $2 \%, *$ denotes significance at $5 \%$.

Table 4 - Composition channel and wage changes: contractual wages and drift. Italy

\begin{tabular}{lccc}
\hline \hline & Contractual & Drift & Total \\
\hline mover & 0.001 & $0.016^{* * *}$ & $0.016^{* * *}$ \\
& $(0.000)$ & $(0.004)$ & $(0.004)$ \\
unempl & -0.005 & 0.006 & 0.001 \\
& $(0.006)$ & $(0.034)$ & $(0.034)$ \\
unempl*mover & -0.003 & $-0.231^{* * *}$ & $-0.234^{* * *}$ \\
& $(0.004)$ & $(0.045)$ & $(0.046)$ \\
$\mathrm{N}$ & 3681845 & 3681844 & 3681844 \\
\hline
\end{tabular}

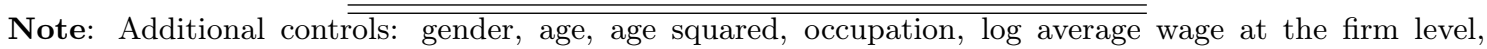
$\log$ average firm size, firm's age, firm's age squared, sector, year and local fixed-effects. Standard errors clustered at the local-year level. Data on negotiated contracts available only starting from 2005. denotes significance at $1 \%, * *$ denotes significance at $2 \%,{ }^{*}$ denotes significance at $5 \%$. 
Table 5 - The reaction of wages of low- and high-skilled occupations

\begin{tabular}{|c|c|c|c|c|c|c|c|c|}
\hline & \multicolumn{4}{|c|}{ France } & \multicolumn{4}{|c|}{ Italy } \\
\hline & \multirow{2}{*}{$\begin{array}{c}\text { prob. } \\
\text { Low } \\
{[1]}\end{array}$} & \multirow{2}{*}{$\begin{array}{c}\text { moving } \\
\text { High } \\
{[2]}\end{array}$} & \multicolumn{2}{|c|}{ delta log wage } & \multicolumn{2}{|c|}{ prob. moving } & \multicolumn{2}{|c|}{ delta log wage } \\
\hline & & & $\begin{array}{c}\text { Low } \\
{[3]}\end{array}$ & $\begin{array}{c}\text { High } \\
\text { [4] }\end{array}$ & $\begin{array}{l}\text { Low } \\
{[5]}\end{array}$ & $\begin{array}{c}\text { High } \\
{[6]}\end{array}$ & $\begin{array}{l}\text { Low } \\
{[7]}\end{array}$ & $\begin{array}{c}\text { High } \\
{[8]}\end{array}$ \\
\hline mover & & & $\begin{array}{c}0.006 \\
(0.003)\end{array}$ & $\begin{array}{c}0.029^{* * *} \\
(0.005)\end{array}$ & & & $\begin{array}{c}0.017^{* * *} \\
(0.001)\end{array}$ & $\begin{array}{c}0.037^{* * *} \\
(0.003)\end{array}$ \\
\hline unemp & $\begin{array}{l}-0.020 \\
(0.012)\end{array}$ & $\begin{array}{c}-0.004 \\
(0.013)\end{array}$ & $\begin{array}{c}-0.014^{*} \\
(0.007)\end{array}$ & $\begin{array}{c}0.005 \\
(0.005)\end{array}$ & $\begin{array}{c}-0.134^{* * *} \\
(0.030)\end{array}$ & $\begin{array}{l}-0.045 \\
(0.061)\end{array}$ & $\begin{array}{c}0.015 \\
(0.012)\end{array}$ & $\begin{array}{c}-0.021 \\
(0.018)\end{array}$ \\
\hline unemp*mov & & & $\begin{array}{l}-0.056 \\
(0.031)\end{array}$ & $\begin{array}{c}-0.188^{* * *} \\
(0.052)\end{array}$ & & & $\begin{array}{c}-0.127^{* * *} \\
(0.019)\end{array}$ & $\begin{array}{c}-0.093^{* *} \\
(0.041)\end{array}$ \\
\hline $\mathrm{N}$ & 3457370 & 2322906 & 3403622 & 2302557 & 4455212 & 3134267 & 4455212 & 3134267 \\
\hline
\end{tabular}

Note: additional controls: whether full time worker, firm's size, mean wage at the firm level, firm's age linear and squared (all referred to the t-1 period), individual, year, sector, and local fixed-effects. Standard errors clustered at the local-year level. $* * *$ denotes significance at $1 \%$, ** denotes significance at $2 \%$, * denotes significance at $5 \%$.

Table 6 - The reaction of wages of temporary and permanent workers

\begin{tabular}{|c|c|c|c|c|c|c|c|c|}
\hline & \multicolumn{4}{|c|}{ France } & \multicolumn{4}{|c|}{ Italy } \\
\hline & \multirow{2}{*}{$\begin{array}{c}\text { prob. } \\
\text { Temp. } \\
\text { [1] }\end{array}$} & \multirow{2}{*}{$\begin{array}{c}\text { moving } \\
\text { Perm. } \\
{[2]}\end{array}$} & \multicolumn{2}{|c|}{ delta log wage } & \multicolumn{2}{|c|}{ prob. moving } & \multicolumn{2}{|c|}{ delta log wage } \\
\hline & & & $\begin{array}{c}\text { Temp. } \\
{[3]}\end{array}$ & $\begin{array}{c}\text { Perm. } \\
{[4]}\end{array}$ & Temp. & $\begin{array}{c}\text { Perm. } \\
{[6]}\end{array}$ & $\begin{array}{l}\text { Temp. } \\
\text { [7] }\end{array}$ & $\begin{array}{c}\text { Perm. } \\
{[8]}\end{array}$ \\
\hline mover & & & $\begin{array}{l}-0.004 \\
(0.010)\end{array}$ & $\begin{array}{c}0.017^{* * *} \\
(0.004)\end{array}$ & & & $\begin{array}{c}-0.004 \\
(0.003)\end{array}$ & $\begin{array}{c}0.034^{* * *} \\
(0.002)\end{array}$ \\
\hline & $\begin{array}{c}-0.159^{*} \\
(0.069)\end{array}$ & $\begin{array}{c}-0.003 \\
(0.015)\end{array}$ & $\begin{array}{l}-0.022 \\
(0.044)\end{array}$ & $\begin{array}{l}-0.003 \\
(0.005)\end{array}$ & $\begin{array}{c}-0.727^{* * *} \\
(0.092)\end{array}$ & $\begin{array}{c}-0.078^{* *} \\
(0.034)\end{array}$ & $\begin{array}{l}-0.001 \\
(0.027)\end{array}$ & $\begin{array}{c}0.009 \\
(0.011)\end{array}$ \\
\hline unemp*mover & & & $\begin{array}{l}-0.052 \\
(0.108)\end{array}$ & $\begin{array}{c}-0.124^{* *} \\
(0.049)\end{array}$ & & & $\begin{array}{c}-0.111^{* * *} \\
(0.028)\end{array}$ & $\begin{array}{c}-0.147^{* * *} \\
(0.024)\end{array}$ \\
\hline $\mathrm{N}$ & 105326 & 3242390 & 85983 & 3216151 & 441280 & 7148199 & 441280 & 7148199 \\
\hline
\end{tabular}

Note: additional controls: whether full time worker, firm's size, mean wage at the firm level, firm's age linear and squared (all referred to the t-1 period), individual, year, sector and local fixed-effects. The period of estimation is limited to 2002-2016 as labor contract information is not available before. Standard errors clustered at the local-year level. ${ }^{* * *}$ denotes significance at $1 \%,{ }^{* *}$ denotes significance at $2 \%,{ }^{*}$ denotes significance at $5 \%$.

Table 7 - The reaction of wages of small and large firms (threshold at 50 employees)

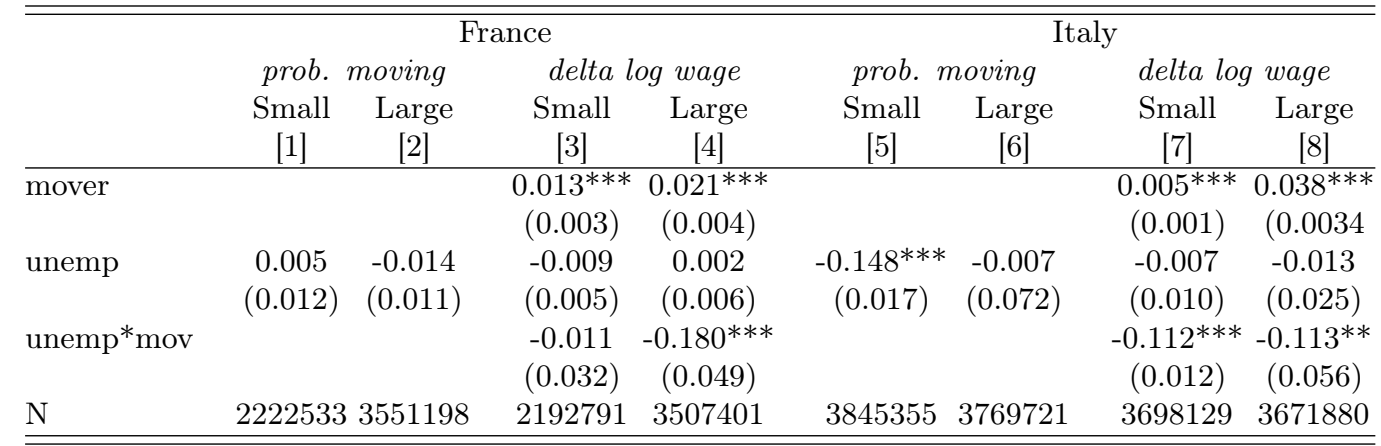

Note: additional controls: whether full time worker, firm's size, mean wage at the firm level, firm's age linear and squared (all referred to the t-1 period), individual, year, sector and local fixed-effects. Standard errors clustered at the local-year level. $* * *$ denotes significance at $1 \%, * *$ denotes significance at $2 \%, *$ denotes significance at $5 \%$. 
Table 8 - Probability of moving and wage changes in newly-born (firm age lower than the $25^{\text {th }}$ percentile and size smaller than the median) and old firms (age higher than the $75^{\text {th }}$ percentile).

\begin{tabular}{|c|c|c|c|c|c|c|}
\hline & \multicolumn{3}{|c|}{ prob. moving } & \multicolumn{3}{|c|}{ delta log wage } \\
\hline & old & young & young & old & young & young \\
\hline & & & $\begin{array}{c}\text { small } \\
{[3]}\end{array}$ & & & $\begin{array}{c}\text { small } \\
{[6]}\end{array}$ \\
\hline & \multicolumn{6}{|c|}{ France } \\
\hline \multirow[t]{2}{*}{ mover } & & & & $0.017^{* * *}$ & 0.010 & $0.013^{* * *}$ \\
\hline & & & & $(0.004)$ & $(0.008)$ & $(0.004)$ \\
\hline \multirow{2}{*}{ unempl } & -0.040 & -0.023 & -0.008 & -0.018 & 0.003 & $-0.029 * *$ \\
\hline & $(0.027)$ & $(0.012)$ & $(0.024)$ & $(0.011)$ & $(0.013)$ & $(0.012)$ \\
\hline \multirow[t]{2}{*}{ unempl*mover } & & & & $-0.104 * * *$ & -0.025 & -0.025 \\
\hline & & & & $(0.040)$ & $(0.085)$ & $(0.045)$ \\
\hline \multirow[t]{2}{*}{$\mathrm{N}$} & 1284351 & 1438432 & 715713 & 1264522 & 1422522 & 703787 \\
\hline & \multicolumn{6}{|c|}{ Italy } \\
\hline \multirow[t]{2}{*}{ mover } & & & & $0.023^{* * *}$ & $0.019 * * *$ & $0.008^{* * *}$ \\
\hline & & & & $(0.003)$ & $(0.004)$ & $(0.002)$ \\
\hline \multirow[t]{2}{*}{ unempl } & 0.048 & -0.152 & $-0.161^{*}$ & -0.032 & 0.043 & 0.020 \\
\hline & $(0.054)$ & $(0.105)$ & $(0.093)$ & $(0.025)$ & $(0.030)$ & $(0.017)$ \\
\hline \multirow[t]{2}{*}{ unempl*mover } & & & & $-0.142^{* * *}$ & $-0.147^{* * *}$ & $-0.156^{* * *}$ \\
\hline & & & & $(0.034)$ & $(0.047)$ & $(0.015)$ \\
\hline $\mathrm{N}$ & 2137193 & 1649133 & 1016515 & 2101895 & 1546159 & 941891 \\
\hline
\end{tabular}

Note: $D_{\text {age }} \overline{\overline{\text { refers to the age of the firm in } t \text { (whether less than the } 25^{\text {th }} \text { percentile or more }}}$ than the $75^{\text {th }}$ percentile). Columns 1, 2, 4 and 5 look at all workers; columns 3 and 6 look at workers employed in $t-1$ in small firms (smaller than the median). Additional controls: whether full time worker, firm's size, mean wage at the firm level, firm's age linear and squared (all referred to the t-1 period), individual, year, sector and local fixed-effects. Standard errors clustered at the local-year level. *** denotes significance at $1 \%,{ }^{* *}$ denotes significance at $2 \%, *$ denotes significance at $5 \%$.

Table 9 - Summary statistics of the probability of changing labor market status, standard deviation

\begin{tabular}{lcc}
\hline \hline & \multicolumn{2}{c}{ Standard deviation } \\
& {$[1]$} & {$[2]$} \\
& France & Italy \\
\hline Prob. changing employer (EE flows) & 0.021 & 0.028 \\
Prob. exiting employment (EN flows) & 0.058 & 0.064 \\
Prob. entering employment (NE flows) & 0.073 & 0.074 \\
\hline \hline
\end{tabular}


Table 10 - Correlation among the unemployment rate and flows in and out employment (EN and NE).

\begin{tabular}{lccc}
\hline \hline & $\Delta$ UR & EN & NE \\
\hline & & France & \\
$\Delta$ Unemployment rate (UR) & 1 & & \\
Prob. exiting employment (EN flows) & 0.003 & 1 & \multirow{2}{*}{ Italy } \\
Prob. entering employment (NE flows) & -0.004 & 0.876 & 1 \\
\hline & & & \\
$\Delta$ Unemployment rate (UR) & 1 & 1 & \\
Prob. exiting employment (EN flows) & 0.208 & 1 & \\
Prob. entering employment (NE flows) & -0.145 & 0.511 & 1 \\
\hline
\end{tabular}

Note: The unemployment rate is the unemployment rate at the market level computed from the Labour Force Survey (from 2003), EN NE flows are the composition adjusted employment to non employment, non employment to employment flows (see text).

Table 11 - The reaction of wages to (proxies of) outside options: France

\begin{tabular}{|c|c|c|c|c|c|c|}
\hline \multirow{4}{*}{ mover $0.008^{* * *}$} & \multicolumn{6}{|c|}{ Dependent variable: delta log wage } \\
\hline & \multicolumn{4}{|c|}{ All } & \multirow{2}{*}{$\begin{array}{c}\text { Movers } \\
{[5]}\end{array}$} & \multirow{2}{*}{$\begin{array}{c}\text { Stayers } \\
{[6]}\end{array}$} \\
\hline & [1] & {$[2]$} & {$[3]$} & {$[4]$} & & \\
\hline & $\begin{array}{c}0.016^{* * *} \\
(0.000)\end{array}$ & $\begin{array}{c}0.009^{* * *} \\
(0.002)\end{array}$ & $\begin{array}{c}0.008^{* * *} \\
(0.001)\end{array}$ & $(0.001)$ & & \\
\hline unemp & $\begin{array}{c}-0.085^{* * *} \\
(0.004)\end{array}$ & $\begin{array}{c}-0.078^{* * *} \\
(0.014)\end{array}$ & $\begin{array}{c}-0.096^{* * *} \\
(0.017)\end{array}$ & $\begin{array}{c}-0.080^{* * *} \\
(0.014)\end{array}$ & $\begin{array}{c}-0.142^{* * *} \\
(0.036)\end{array}$ & $\begin{array}{c}-0.077^{* * *} \\
(0.013)\end{array}$ \\
\hline unemp*mover & & $\begin{array}{c}-0.095^{* * *} \\
(0.021)\end{array}$ & & & & \\
\hline EE flows & $\begin{array}{c}0.087^{* * *} \\
(0.004)\end{array}$ & $\begin{array}{c}0.086^{* * *} \\
(0.009)\end{array}$ & & $\begin{array}{c}0.096^{* * *} \\
(0.009)\end{array}$ & $\begin{array}{c}0.231^{* * *} \\
(0.044)\end{array}$ & $\begin{array}{c}0.079^{* * *} \\
(0.006)\end{array}$ \\
\hline EN flows & & & $\begin{array}{c}-0.011^{* *} \\
(0.004)\end{array}$ & $\begin{array}{l}-0.002 \\
(0.004)\end{array}$ & $\begin{array}{c}-0.036^{*} \\
(0.018)\end{array}$ & $\begin{array}{c}0.003 \\
(0.004)\end{array}$ \\
\hline NE flows & & & $\begin{array}{c}0.044^{* * *} \\
(0.004)\end{array}$ & $\begin{array}{c}0.042^{* * *} \\
(0.004)\end{array}$ & $\begin{array}{c}0.070 * * * \\
(0.018)\end{array}$ & $\begin{array}{c}0.040 * * * \\
(0.004)\end{array}$ \\
\hline $\mathrm{N}$ & 5888996 & 5888996 & 5888723 & 5888723 & 500294 & 5388429 \\
\hline
\end{tabular}

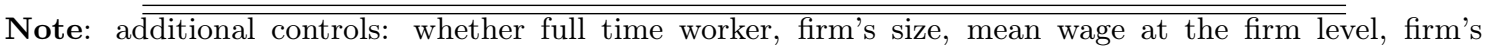
age linear and squared (all referred to the t-1 period), market, year, sector fixed-effects. Market is the combination of age (3 categories), gender, whether blue collar and department. The unemployment rate is the unemployment rate at the market level computed from the Labour Force Survey (from 2003), EE EN NE flows are the composition adjusted job-to-job, employment to non employment, non employment to employment flows (see text). Standard errors clustered by type-time. *** denotes significance at $1 \%$, ** denotes significance at $2 \%, *$ denotes significance at $5 \%$. 
Table 12 - The reaction of wages to (proxies of) outside options: Italy

\begin{tabular}{|c|c|c|c|c|c|c|}
\hline & \multicolumn{6}{|c|}{ Dependent variable: delta log wage } \\
\hline & & & All & & Movers & Stayers \\
\hline & [1] & [2] & [3] & [4] & {$[5]$} & [6] \\
\hline mover & $\begin{array}{c}0.012^{* * *} \\
(0.001)\end{array}$ & $\begin{array}{c}0.013^{* * *} \\
(0.002)\end{array}$ & $\begin{array}{c}0.012^{* * *} \\
(0.001)\end{array}$ & $\begin{array}{c}0.012^{* * *} \\
(0.001)\end{array}$ & & \\
\hline unemp & $\begin{array}{c}0.002 \\
(0.003)\end{array}$ & $\begin{array}{c}0.003 \\
(0.003)\end{array}$ & $\begin{array}{c}0.001 \\
(0.003)\end{array}$ & $\begin{array}{c}0.001 \\
(0.003)\end{array}$ & $\begin{array}{c}-0.003 \\
(0.009)\end{array}$ & $\begin{array}{c}0.002 \\
(0.003)\end{array}$ \\
\hline unemp*mover & & $\begin{array}{c}-0.015^{* *} \\
(0.007)\end{array}$ & & & & \\
\hline EE flows & $\begin{array}{c}0.054^{* * * *} \\
(0.013)\end{array}$ & $\begin{array}{c}0.054^{* * *} \\
(0.013)\end{array}$ & & $\begin{array}{c}0.049^{* * *} \\
(0.013)\end{array}$ & $\begin{array}{c}0.140^{* * *} \\
(0.033)\end{array}$ & $\begin{array}{c}0.018^{* * *} \\
(0.007)\end{array}$ \\
\hline EN flows & & & $\begin{array}{c}-0.033^{* * *} \\
(0.007)\end{array}$ & $\begin{array}{c}-0.026^{* * *} \\
(0.007)\end{array}$ & $\begin{array}{c}0.022 \\
(0.027)\end{array}$ & $\begin{array}{c}-0.033^{* * *} \\
(0.007)\end{array}$ \\
\hline NE flows & & & $\begin{array}{c}0.044^{* * *} \\
(0.006)\end{array}$ & $\begin{array}{c}0.040^{* * *} \\
(0.006)\end{array}$ & $\begin{array}{c}0.015 \\
(0.021)\end{array}$ & $\begin{array}{c}0.042^{* * *} \\
(0.006)\end{array}$ \\
\hline $\mathrm{N}$ & 5524007 & 5524007 & 5523785 & 5523785 & 543354 & 4980367 \\
\hline
\end{tabular}

Note: additional controls: whether full time worker, firm's size, mean wage at the firm level, firm's age linear and squared (all referred to the t-1 period), market, year, sector fixed-effects. Market is the combination of age (3 categories), gender, whether blue collar and region. The unemployment rate is the unemployment rate at the market level computed from the Labour Force Survey (from 2004), EE EN NE flows are the composition adjusted job-to-job, employment to non employment, non employment to employment flows (see text). Standard errors clustered by type-time. *** denotes significance at $1 \%,{ }^{* *}$ denotes significance at $2 \%, *$ denotes significance at $5 \%$. 


\section{Appendix A Only males permanent full time workers}

Table A1 - Summary statistics

\begin{tabular}{lcccccc}
\hline \hline & & Italy & & France \\
& All & Stayers & Movers & All & Stayers & Movers \\
& $(1)$ & $(2)$ & $(3)$ & $(1)$ & $(2)$ & $(3)$ \\
\hline Movers (as \% of total empl.) & 0.073 & & & 0.075 & & \\
Daily wage & 91.431 & 91.415 & 91.627 & 96.738 & 96.888 & 94.900 \\
& $(55.149)$ & $(54.898)$ & $(58.221)$ & $(70.593)$ & $(70.948)$ & $(66.040)$ \\
Log wage change & 0.036 & 0.034 & 0.059 & 0.038 & 0.038 & 0.044 \\
& $(0.100)$ & $(0.092)$ & $(0.167)$ & $(0.138)$ & $(0.126)$ & $(0.239)$ \\
Days worked & 287.715 & 296.252 & 179.813 & & & \\
Days paid & $(56.313)$ & $(41.451)$ & $(94.722)$ & & & \\
& & & & 348.011 & 358.078 & 224.021 \\
Age & & & & $(51.772)$ & $(22.222)$ & $(113.974)$ \\
Low skilled workers & 38.653 & 38.727 & 37.724 & 38.675 & 38.829 & 36.775 \\
Firm average wage (log) & $(6.764)$ & $(6.757)$ & $(6.774)$ & $(6.796)$ & $(6.780)$ & $(6.716)$ \\
Firm size (log) & 0.668 & 0.669 & 0.653 & 0.581 & 0.585 & 0.543 \\
& 7.580 & 7.584 & 7.526 & 10.285 & 10.295 & 10.466 \\
Firm age (years) & $(0.402)$ & $(0.397)$ & $(0.460)$ & $(0.414)$ & $(0.399)$ & $(0.950)$ \\
& 4.433 & 4.458 & 4.113 & 5.106 & 5.132 & 4.886 \\
Local unempl. rate & $(2.535)$ & $(2.536)$ & $(2.500)$ & $(2.696)$ & $(2.701)$ & $(2.634)$ \\
& 18.640 & 19.333 & 9.879 & 26.157 & 26.727 & 22.064 \\
& $(13.544)$ & $(13.384)$ & $(12.455)$ & $(21.071)$ & $(21.061)$ & $(19.729)$ \\
Observations & 0.074 & 0.074 & 0.070 & 0.089 & 0.089 & 0.088 \\
\hline \hline
\end{tabular}

Note: Sources: INPS and DADS. Standard deviations within brackets. For movers: workers' and firms' characteristics observed before moving. Low-skilled workers in Italy are those classified by INPS as blue collar workers; in France are those classified as low-skilled workers, drivers, employees in trade and in services to the households. Share firms $>50$ employees refers to the share of workers working in firms with more than 50 employees. Because of data limitations, we use region-level unemployment rates for Italy and Department-level unemployment rates for France. 
Table A2 - Composition channel and job-to-job moves and wage changes. France

\begin{tabular}{lcccccccc}
\hline \hline & prob. moving & \multicolumn{7}{c}{ delta log wage } \\
& {$[1]$} & {$[2]$} & {$[3]$} & {$[4]$} & {$[5]$} & {$[6]$} & {$[7]$} & {$[8]$} \\
\hline mover & & & $0.018^{* * *}$ & $0.017^{* * *}$ & & & $0.022^{* * *}$ & $0.021^{* * *}$ \\
& & & $(0.001)$ & $(0.001)$ & & & $(0.005)$ & $(0.003)$ \\
unempl & $0.137^{* *}$ & $-0.191^{* * *}$ & & & -0.008 & -0.004 & -0.004 & -0.002 \\
& $(0.054)$ & $(0.071)$ & & & $(0.028)$ & $(0.031)$ & $(0.020)$ & $(0.015)$ \\
unempl*mover & & & & & & & -0.047 & -0.043 \\
& & & & & & & $(0.052)$ & $(0.038)$ \\
$\mathrm{N}$ & 1676452 & 1676452 & 1676452 & 1676452 & 1676452 & 1676452 & 1676452 & 1676452 \\
\hline Ind. Fe & No & Yes & No & Yes & No & Yes & No & Yes
\end{tabular}

Note: Additional controls: gender, age, age squared, occupation, log average wage at the firm level, log average firm size, firm's age, firm's age squared, sector, year and local fixed effects. Standard errors clustered at the local-year level.$* *$ denotes significance at $1 \%,{ }^{* *}$ denotes significance at $2 \%,{ }^{*}$ denotes significance at $5 \%$.

Table A3 - Composition channel and job-to-job moves and wage changes. Italy

\begin{tabular}{lcccccccc}
\hline \hline & \multicolumn{7}{c}{ prob. moving } & \multicolumn{7}{c}{ delta log wage } \\
& {$[1]$} & {$[2]$} & {$[3]$} & {$[4]$} & {$[5]$} & {$[6]$} & {$[7]$} & {$[8]$} \\
\hline mover & & & $0.025^{* * *}$ & $0.025^{* * *}$ & & $0.035^{* * *}$ & $0.040^{* * *}$ \\
& & & $(0.002)$ & $(0.002)$ & & & $(0.002)$ & $(0.002)$ \\
unempl & $-0.096^{* *}$ & $-0.101^{* * *}$ & & & -0.011 & -0.021 & 0.003 & -0.004 \\
& $(0.039)$ & $(0.034)$ & & & $(0.013)$ & $(0.014)$ & $(0.013)$ & $(0.014)$ \\
unempl*mover & & & & & & & $-0.134^{* * *}$ & $-0.147^{* * *}$ \\
& & & & & & & $(0.026)$ & $(0.031)$ \\
$\mathrm{N}$ & 4856898 & 4668458 & 4737602 & 4656723 & 4668045 & 4588430 & 4668045 & 4588430 \\
\hline Ind. Fe & No & Yes & No & Yes & No & Yes & No & Yes \\
\hline \hline
\end{tabular}

Note: Additional controls: gender, age, age squared, occupation, log average wage at the firm level, log average firm size, firm's age, firm's age squared, sector, year and local fixed effects. Standard errors clustered at the local-year level .*** denotes significance at $1 \%, * *$ denotes significance at $2 \%, *$ denotes significance at $5 \%$.

Table A4 - Composition channel and wage changes: contractual wages and drift. Italy

\begin{tabular}{lccc}
\hline \hline & Contractual & Drift & Total \\
\hline mover & $0.001^{*}$ & $0.027^{* * *}$ & $0.028^{* * *}$ \\
& $(0.000)$ & $(0.005)$ & $(0.005)$ \\
unempl & -0.005 & 0.020 & 0.016 \\
& $(0.006)$ & $(0.044)$ & $(0.043)$ \\
unempl*mover & -0.004 & $-0.186^{* * *}$ & $-0.189^{* * *}$ \\
& $(0.004)$ & $(0.060)$ & $(0.061)$ \\
$\mathrm{N}$ & 2246472 & 2246471 & 2246471 \\
\hline \hline
\end{tabular}

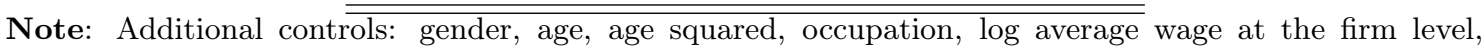
log average firm size, firm's age, firm's age squared, sector, year and local fixed effects. Standard errors clustered at the local-year level. *** denotes significance at $1 \%, * *$ denotes significance at $2 \%, *$ denotes significance at $5 \%$. 
Table A5 - The reaction of wages of low- and high-skilled occupations

\begin{tabular}{lcccccccc}
\hline \hline & \multicolumn{4}{c}{ France } & \multicolumn{4}{c}{ Italy } \\
& prob. moving & \multicolumn{2}{c}{ delta log wage } & prob. moving & \multicolumn{2}{c}{ delta log wage } \\
& Low & High & Low & High & Low & High & Low & High \\
& {$[1]$} & {$[2]$} & {$[3]$} & {$[4]$} & {$[5]$} & {$[6]$} & {$[7]$} & {$[8]$} \\
\hline mover & & & $0.010^{* * *}$ & $0.028^{* * *}$ & & & $0.023^{* * *}$ & $0.055^{* * *}$ \\
& & & $(0.003)$ & $(0.005)$ & & & $(0.001)$ & $(0.004)$ \\
unempl & -0.008 & 0.002 & $-0.016^{* * *}$ & 0.011 & $-0.115^{* *}$ & -0.069 & 0.010 & -0.034 \\
& $(0.013)$ & $(0.020)$ & $(0.005)$ & $(0.007)$ & $(0.031)$ & $(0.080)$ & $(0.013)$ & $(0.023)$ \\
unempl*mover & & & 0.040 & -0.114 & & & $-0.102^{* * *}$ & $-0.121^{* *}$ \\
& & & $(0.026)$ & $(0.058)$ & & & $(0.021)$ & $(0.047)$ \\
$\mathrm{N}$ & 1058502 & 783829 & 1053711 & 781659 & 3221146 & 1527084 & 3155647 & 1512398 \\
\hline
\end{tabular}

Note: additional controls: whether full time worker, firm's size, mean wage at the firm level, firm's age linear and squared (all referred to the t-1 period), individual, year, sector, year and local fixed effects. The period of estimation is limited to $2002-2015$ as labor contract information is not available before. Standard errors clustered at the local-year level. ${ }^{* * *}$ denotes significance at $1 \%,{ }^{* *}$ denotes significance at $2 \%, *$ denotes significance at $5 \%$.

Table A6 - The reaction of wages of small and large firms (threshold at 50 employees)

\begin{tabular}{|c|c|c|c|c|c|c|c|c|}
\hline & \multicolumn{4}{|c|}{ France } & \multicolumn{4}{|c|}{ Italy } \\
\hline & \multirow{2}{*}{$\begin{array}{c}\text { prob. } \\
\text { Small } \\
{[1]}\end{array}$} & \multirow{2}{*}{$\begin{array}{c}\text { moving } \\
\text { Large } \\
{[2]}\end{array}$} & \multicolumn{2}{|c|}{ delta log wage } & \multicolumn{2}{|c|}{ prob. moving } & \multicolumn{2}{|c|}{ delta log wage } \\
\hline & & & $\begin{array}{c}\text { Small } \\
{[3]}\end{array}$ & $\begin{array}{c}\text { Large } \\
{[4]}\end{array}$ & $\begin{array}{c}\text { Small } \\
{[5]}\end{array}$ & $\begin{array}{c}\text { Large } \\
{[6]}\end{array}$ & $\begin{array}{c}\text { Small } \\
{[7]}\end{array}$ & $\begin{array}{c}\text { Large } \\
{[8]}\end{array}$ \\
\hline mover & & & $\begin{array}{c}0.024^{* * *} \\
(0.003)\end{array}$ & $\begin{array}{c}0.021^{* * *} \\
(0.006)\end{array}$ & & & $\begin{array}{c}0.016^{* * *} \\
(0.001)\end{array}$ & $\begin{array}{c}0.050^{* * *} \\
(0.004)\end{array}$ \\
\hline unemp & $\begin{array}{c}0.015 \\
(0.016)\end{array}$ & $\begin{array}{c}-0.004 \\
(0.016)\end{array}$ & $\begin{array}{l}-0.012 \\
(0.007)\end{array}$ & $\begin{array}{c}0.002 \\
(0.005)\end{array}$ & $\begin{array}{c}-0.166^{* * *} \\
(0.018)\end{array}$ & $\begin{array}{c}0.032 \\
(0.077)\end{array}$ & $\begin{array}{l}-0.003 \\
(0.011)\end{array}$ & $\begin{array}{c}-0.019 \\
(0.027)\end{array}$ \\
\hline unemp*mov & & & $\begin{array}{c}0.009 \\
(0.030)\end{array}$ & $\begin{array}{c}-0.098 \\
(0.062)\end{array}$ & & & $\begin{array}{c}-0.133^{* * *} \\
(0.013)\end{array}$ & $\begin{array}{l}-0.056 \\
(0.067)\end{array}$ \\
\hline $\mathrm{N}$ & 694673 & 1151255 & 691616 & 1147418 & 2267077 & 2274734 & 2215951 & 2253408 \\
\hline
\end{tabular}

Note: additional controls: whether full time worker, firm's size, mean wage at the firm level, firm's age linear and squared (all referred to the t-1 period), individual, year, sector, year and local fixed effects. The period of estimation is limited to 2002-2015 as labor contract information is not available before. Standard errors clustered at the local-year level. ${ }^{* * *}$ denotes significance at $1 \%, * *$ denotes significance at $2 \%, *$ denotes significance at $5 \%$. 
Table A7 - Probability of moving and wage changes in newly-born (firm age lower than the $25^{t h}$ percentile and size smaller than the median) and old firms (age higher than the $75^{\text {th }}$ percentile).

\begin{tabular}{|c|c|c|c|c|c|c|}
\hline & \multicolumn{3}{|c|}{ prob. moving } & \multicolumn{3}{|c|}{ delta log wage } \\
\hline & old & young & $\begin{array}{c}\text { young } \\
\text { small }\end{array}$ & old & young & $\begin{array}{c}\text { young } \\
\text { small }\end{array}$ \\
\hline & [1] & {$[2]$} & [3] & [4] & {$[5]$} & [6] \\
\hline & \multicolumn{6}{|c|}{ France } \\
\hline mover & & & & $\begin{array}{c}0.021^{* * *} \\
(0.008)\end{array}$ & $\begin{array}{c}0.016^{* *} \\
(0.004)\end{array}$ & $\begin{array}{c}0.016^{* * *} \\
(0.005)\end{array}$ \\
\hline unempl & $\begin{array}{l}-0.021 \\
(0.013)\end{array}$ & $\begin{array}{c}0.037 \\
(0.048)\end{array}$ & $\begin{array}{c}0.015 \\
(0.042)\end{array}$ & $\begin{array}{c}0.003 \\
(0.006)\end{array}$ & $\begin{array}{l}-0.008 \\
(0.010)\end{array}$ & $\begin{array}{c}-0.008 \\
(0.013)\end{array}$ \\
\hline unempl*mover & & & & $\begin{array}{l}-0.105 \\
(0.091)\end{array}$ & $\begin{array}{l}-0.029 \\
(0.043)\end{array}$ & $\begin{array}{c}0.038 \\
(0.051)\end{array}$ \\
\hline $\mathrm{N}$ & 467448 & 399738 & 228420 & 465917 & 397738 & 227055 \\
\hline & & Italy & & & & \\
\hline mover & & & & $\begin{array}{c}0.041^{* * *} \\
(0.004)\end{array}$ & $\begin{array}{c}0.028^{* * *} \\
(0.005)\end{array}$ & $\begin{array}{c}0.014^{* * *} \\
(0.002)\end{array}$ \\
\hline unempl & $\begin{array}{c}0.036 \\
(0.073)\end{array}$ & $\begin{array}{l}-0.144 \\
(0.095)\end{array}$ & $\begin{array}{c}-0.187^{* *} \\
(0.085)\end{array}$ & $\begin{array}{l}-0.043 \\
(0.029)\end{array}$ & $\begin{array}{l}0.061^{*} \\
(0.031)\end{array}$ & $\begin{array}{c}0.048^{* * * *} \\
(0.018)\end{array}$ \\
\hline unempl*mover & & & & $\begin{array}{c}-0.185^{* * *} \\
(0.041)\end{array}$ & $\begin{array}{c}-0.132^{* *} \\
(0.052)\end{array}$ & $\begin{array}{c}-0.159^{* * *} \\
(0.017)\end{array}$ \\
\hline $\mathrm{N}$ & 1293861 & 1101101 & 656039 & 1285518 & 1060797 & 624282 \\
\hline
\end{tabular}

Note: $D_{\text {age }}$ refers to the age of the firm in $t$ (whether less than the $25^{\text {th }}$ percentile or more than the $75^{\text {th }}$ percentile). Columns 1, 2, 4 and 5 look at all workers; columns 3 and 6 look at workers employed in $t-1$ in small firms (smaller than the median). Additional controls: whether full time worker, firm's size, mean wage at the firm level, firm's age linear and squared (all referred to the t- 1 period), individual, year, sector and local fixed effects. Standard errors clustered at the local-year level. ${ }^{* * *}$ denotes significance at $1 \%, * *$ denotes significance at $2 \%, *$ denotes significance at $5 \%$.

Table A8 - The reaction of wages to (proxies of) outside options: France

\begin{tabular}{lcccccc}
\hline \hline & \multicolumn{6}{c}{ Dependent variable: delta log wage } \\
& {$[1]$} & {$[2]$} & {$[3]$} & {$[4]$} & Movers & Stayers \\
& $0.015^{* * *}$ & $0.022^{* * *}$ & $0.016^{* * *}$ & $0.015^{* * *}$ & {$[6]$} \\
\hline mover & $(0.001)$ & $(0.003)$ & $(0.001)$ & $(0.001)$ & & \\
& $-0.024^{* * *}$ & $-0.019^{* * *}$ & $-0.026^{* * *}$ & $-0.023^{* * *}$ & 0.040 & $-0.029^{* * *}$ \\
unemp & $(0.004)$ & $(0.005)$ & $(0.007)$ & $(0.006)$ & $(0.025)$ & $(0.007)$ \\
unemp*mover & & $-0.070^{* *}$ & & & & \\
EE flows & $0.081^{* * * *}$ & $0.080^{* * *}$ & & $0.082^{* * *}$ & -0.044 & $0.098^{* * *}$ \\
& $(0.005)$ & $(0.018)$ & & $(0.018)$ & $(0.056)$ & $(0.012)$ \\
EN flows & & & $0.014^{* *}$ & $0.014^{* *}$ & $0.067^{* * *}$ & 0.008 \\
& & & $(0.006)$ & $(0.006)$ & $(0.020)$ & $(0.005)$ \\
NE flows & & & 0.009 & 0.001 & $-0.119^{* * *}$ & 0.010 \\
& & & $(0.006)$ & $(0.006)$ & $(0.024)$ & $(0.006)$ \\
$\mathrm{N}$ & 1903721 & 1903721 & 1903655 & 1903655 & 139871 & 1763783 \\
\hline \hline
\end{tabular}

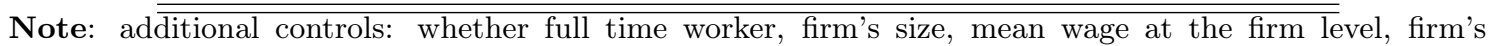
age linear and squared (all referred to the t-1 period), market, year, sector fixed effects. Market is the combination of age (3 categories), gender, whether blue collar and department. The unemployment rate is the unemployment rate at the market level computed from the Labour Force Survey (from 2003), EE EN NE flows are the composition adjusted job-to-job, employment to non employment, non employment to employment flows (see text). Standard errors clustered by type-time. ${ }^{* * *}$ denotes significance at $1 \%$, ** denotes significance at $2 \%, *$ denotes significance at $5 \%$. 
Table A9 - The reaction of wages to (proxies of) outside options: Italy

\begin{tabular}{|c|c|c|c|c|c|c|}
\hline & \multicolumn{6}{|c|}{ Dependent variable: delta log wage } \\
\hline & & & All & & Movers & Stayers \\
\hline & {$[1]$} & [2] & [3] & [4] & {$[5]$} & [6] \\
\hline mover & $\begin{array}{c}0.022^{* * *} \\
(0.001)\end{array}$ & $\begin{array}{c}0.021^{* * *} \\
(0.001)\end{array}$ & $\begin{array}{c}0.022^{* * *} \\
(0.001)\end{array}$ & $\begin{array}{c}0.022^{* * *} \\
(0.001)\end{array}$ & & \\
\hline unemp & $\begin{array}{c}0.002 \\
(0.004)\end{array}$ & $\begin{array}{c}0.002 \\
(0.004)\end{array}$ & $\begin{array}{c}0.002 \\
(0.004)\end{array}$ & $\begin{array}{c}0.002 \\
(0.004)\end{array}$ & $\begin{array}{c}0.003 \\
(0.013)\end{array}$ & $\begin{array}{c}0.002 \\
(0.004)\end{array}$ \\
\hline unemp*mover & & $\begin{array}{c}0.010 \\
(0.011)\end{array}$ & & & & \\
\hline EE flows & $\begin{array}{c}0.051^{* * * *} \\
(0.013)\end{array}$ & $\begin{array}{c}0.051^{* * *} \\
(0.013)\end{array}$ & & $\begin{array}{c}0.043^{* * *} \\
(0.013)\end{array}$ & $\begin{array}{l}0.095^{*} \\
(0.043)\end{array}$ & $\begin{array}{l}0.016^{*} \\
(0.008)\end{array}$ \\
\hline EN flows & & & $\begin{array}{c}-0.164^{* * *} \\
(0.038)\end{array}$ & $\begin{array}{c}-0.162^{\text {*** }} \\
(0.037)\end{array}$ & $\begin{array}{l}-0.171 \\
(0.142)\end{array}$ & $\begin{array}{c}-0.165^{* * *} \\
(0.036)\end{array}$ \\
\hline NE flows & & & $\begin{array}{c}0.112^{* * *} \\
(0.016)\end{array}$ & $\begin{array}{c}0.108^{* * *} \\
(0.016)\end{array}$ & $\begin{array}{c}0.279 * * * \\
(0.059)\end{array}$ & $\begin{array}{c}0.095^{* * *} \\
(0.013)\end{array}$ \\
\hline $\mathrm{N}$ & 3328895 & 3328895 & 3328826 & 3328826 & 262567 & 3066235 \\
\hline
\end{tabular}

Note: additional controls: whether full time worker, firm's size, mean wage at the firm level, firm's age linear and squared (all referred to the t-1 period), market, year, sector fixed effects. Market is the combination of age (3 categories), gender, whether blue collar and department. The unemployment rate is the unemployment rate at the market level computed from the Labour Force Survey (from 2003), EE EN NE flows are the composition adjusted job-to-job, employment to non employment, non employment to employment flows (see text). Standard errors clustered by type-time. ${ }^{* * *}$ denotes significance at $1 \%$, ** denotes significance at $2 \%,{ }^{*}$ denotes significance at $5 \%$. 


\section{Appendix B Regional unemployment rate}

Table B1 - Observed cyclicality of job-to-job moves and wage changes. France

\begin{tabular}{lcccccccc}
\hline \hline & prob. moving & & \multicolumn{5}{c}{ delta log wage } & \\
& {$[1]$} & {$[2]$} & {$[3]$} & {$[4]$} & {$[5]$} & {$[6]$} & {$[7]$} & {$[8]$} \\
\hline mover & & & $0.010^{* * *}$ & $0.008^{* * *}$ & $0.026^{* * *}$ & $0.026^{* * *}$ & & \\
& & & $(0.002)$ & $(0.002)$ & $(0.008)$ & $(0.008)$ & & \\
unemp & -0.218 & -0.035 & & & $-0.158^{* * *}$ & -0.104 & $-0.174^{* * *}$ & -0.122 \\
& $(0.117)$ & $(0.187)$ & & & $(0.050)$ & $(0.079)$ & $(0.051)$ & $(0.080)$ \\
unemp*mover & & & & & $-0.187^{*}$ & $-0.214^{* * *}$ & & \\
& & & & & $(0.085)$ & $(0.082)$ & & \\
$\mathrm{N}$ & 5856265 & 5856265 & 5787567 & 5787503 & 5787567 & 5787503 & 5787567 & 5781503 \\
Ind. Fe & No & Yes & No & Yes & No & Yes & No & Yes \\
\hline \hline
\end{tabular}

Note: Additional controls: gender, age, age squared, occupation, log average wage at the firm level, log average firm size, firm's age, firm's age squared, sector fixed effect, region fixed effects. Standard errors clustered at the region-year level.

Table B2 - Observed cyclicality of job-to-job moves and wage changes. Italy

\begin{tabular}{|c|c|c|c|c|c|c|c|c|}
\hline & \multicolumn{2}{|c|}{ prob. moving } & \multicolumn{6}{|c|}{ delta log wage } \\
\hline & {$[1]$} & [2] & [3] & [4] & {$[5]$} & [6] & {$[7]$} & {$[8]$} \\
\hline mover & & & $\begin{array}{c}0.016^{* * *} \\
(0.001)\end{array}$ & $\begin{array}{c}0.013^{* * *} \\
(0.002)\end{array}$ & & & $\begin{array}{c}0.029^{* * *} \\
(0.002)\end{array}$ & $\begin{array}{c}0.031^{* * *} \\
(0.002)\end{array}$ \\
\hline unemp & $\begin{array}{c}-0.173 * * * \\
(0.062)\end{array}$ & $\begin{array}{c}-0.253^{* * *} \\
(0.069)\end{array}$ & & & $\begin{array}{l}-0.034 \\
(0.024)\end{array}$ & $\begin{array}{c}-0.060^{*} \\
(0.027)\end{array}$ & $\begin{array}{l}-0.016 \\
(0.023)\end{array}$ & $\begin{array}{l}-0.038 \\
(0.026)\end{array}$ \\
\hline unemp*mover & & & & & & & $\begin{array}{c}-0.175^{* * * *} \\
(0.028)\end{array}$ & $\begin{array}{c}-0.191^{* * *} \\
(0.032)\end{array}$ \\
\hline $\mathrm{N}$ & 7700989 & 7565255 & 7700989 & 7565255 & 7700989 & 7565255 & 7700989 & 7565255 \\
\hline Ind. $\mathrm{Fe}$ & No & Yes & No & Yes & No & Yes & No & Yes \\
\hline
\end{tabular}

Note: Additional controls: gender, age, age squared, occupation, log average wage at the firm level, log average firm size, firm's age, firm's age squared, sector fixed effect, region fixed effects. Standard errors clustered at the region-year level. 